\title{
Project Lifecycle Management (PLM): evolution and state of the art
}

\author{
Daniela Silva dos Santos ${ }^{a}$ Diane Aparecida Reis ${ }^{a}$, André Leme Fleury ${ }^{a}$ \\ Universidade de São Paulo - USP, São Paulo, SP, Brasil \\ e-mails: engenheiradaniela.s@gmail.com; diane.reis@hotmail.com; andreleme.fleury@gmail.com
}

\begin{abstract}
Intelligent manufacturing has produced a revolutionary change, mainly driven by the current competitive world, reinforcing the importance of inserting Product Lifecycle Management (PLM) approach. PLM emerges with the aim of efficiently managing product-related information throughout the product lifecycle with sustainability. It also satisfies the interest in managing the services and products lifecycle, and in the case of products, their management, from their insertion in production processes, to their lifecycle end, generating a closed management cycle. This paper aims mainly to understand how the concept of PLM is being approached and defined by academics. For this, a systematic literature review with bibliometrics, networks and contents analysis were applied. The goal of this paper to evidencing the main PLM definitions, providing a comprehensive view of the current researches and raising knowledge gaps for future research about it.
\end{abstract}

Keywords: Product Lifecycle, Product Lifecycle Management (PLM), Lifecycle Management.

\section{Introduction}

Currently, new business challenges are constantly emerging in a scenario of short product lifecycles, increase of outsourcing, mass customization demands, geographical dispersal of teams and fast depreciation. This scenario enhances collaborative and integrated engineering, caused by the management need of products are increasing in diversity and complexity (Ming et al., 2008; Fortineau et al., 2013). This demands the reduction of the time-to-market and production costs, while improving quality (Fortineau et al., 2013), resulting in a highly competitive and fast change of the global marketplace, challenging for a modern collaborative business environment, requiring the industry to consider design, control and optimization of the whole product lifecycle, besides the capability to operate in a dynamic global environment. It also demands the acquisition of new capabilities for competitive advantages in the current Internet Economy (Jun et al., 2009; Young et al., 2007; Ming et al., 2008). This way, the management of the lifecycle becomes critical to innovations, meeting the customer needs, without driving up costs, sacrificing quality or delaying deliveries (Jun et al., 2009; Young et al., 2007).

Academics and industrial researchers engage tremendous efforts in research and develop industrial information technologies, pursuing more competitive business advantages in product lifecycle, highlighting the increasing interest in the benefits of the effective use of lifecycle Big Data (Ming et al., 2008; Zhang et al., 2017b). This way, information management has received a considerable attention, mainly because organizations work in a complex business environment characterized by information overload, high levels of competitiveness and acceleration of technological change. These efforts led to the Product Lifecycle Management (PLM) software, offering powerful tools and enabling high levels of manageable information (Soto-Acosta et al., 2016; Jun et al., 2009; Sharma, 2005).

PLM has been recognized for evidencing challenges and opportunities, once modern technological advances have resulted in innumerable complex systems, processes, and products, and this increasing complexity offers considerable challenges in design, analyses, production and management, for their whole lifecycle (Venkatasubramanian, 2005). A new knowledge research field is thus provided which aims to assist in the current industry challenges (Fortineau et al., 2013).

Therefore, this study aims to understand and to evidence: How is the PLM concept being approached and defined by academics? The paper also investigated the evolution of PLM, providing an overview of the researches already conducted and the knowledge gaps for future researches. A systematic literature review was applied, assisted by bibliometrics, networks and contents analysis.

This paper comprises five sections. The first section details the context and relevance of this study. Section two presents the method. Section three evidences the results. Section four discusses the results, while section five provides the conclusions. 


\section{Research method}

The research conducted a systematic literature review to understand the use of PLM by academics. The purpose was to evidence the state of the art about PLM, providing a comprehensive view of the research already conducted about the theme and the possible knowledge gaps for future research.

The systematic literature review was used for searching the state of the art to detect the advances and the limitations of the research already published (Palmarini et al., 2018). This allows identifying the future research opportunities, the research gaps and evidencing the subject structure, causes, effects and processes (Dikici et al., 2018; Maier et al., 2016).

\subsection{Sample and procedures}

The sample of analyzed papers is a result of searches in two databases, Scopus and Web of Science (WoS).

Figure 1 summarizes the research based on 962 documents, selected after different filters, resulting in 469 papers about the subject of interest, used for the bibliometrics and networks analysis, and 56 most relevant articles for full reading, forming the database for this article content analysis. The method is detailed in the next topics.

\subsection{Research method steps}

Bibliometrics analysis uses empirical evidence to explore a research field (Neely, 2005), summarizing the major research trends and subjects (Kolle et al., 2017; Yu et al., 2016; Zhang et al., 2017b), guiding future researches (Zhang et al., 2017b). Assuming that the authors of a theme cited the most relevant researches in the field, evidencing the most relevant citations and co-citations (Ramos-Rodríguez \& Ruíz-Navarro, 2004). The network analysis evidences a photograph of the publications (Takey $\&$ Carvalho, 2016). The application of bibliometrics and networks analysis allows the active investigation of publications (Yataganbaba et al., 2017). The content analysis assists in the conceptualization of the research in different ways (Hazen et al., 2015), assisting in the analysis of the information (Wasike, 2017; Arslan, 2012) and evidencing common practices, interpretations, and relationships (Allen et al., 2014).

The research methods steps were first analyzing the number of publications per year and per journal, highlighting the evolution of the subject published over the years, and the journals that published about it. The second step, all the publications were analyzed to develop a coding

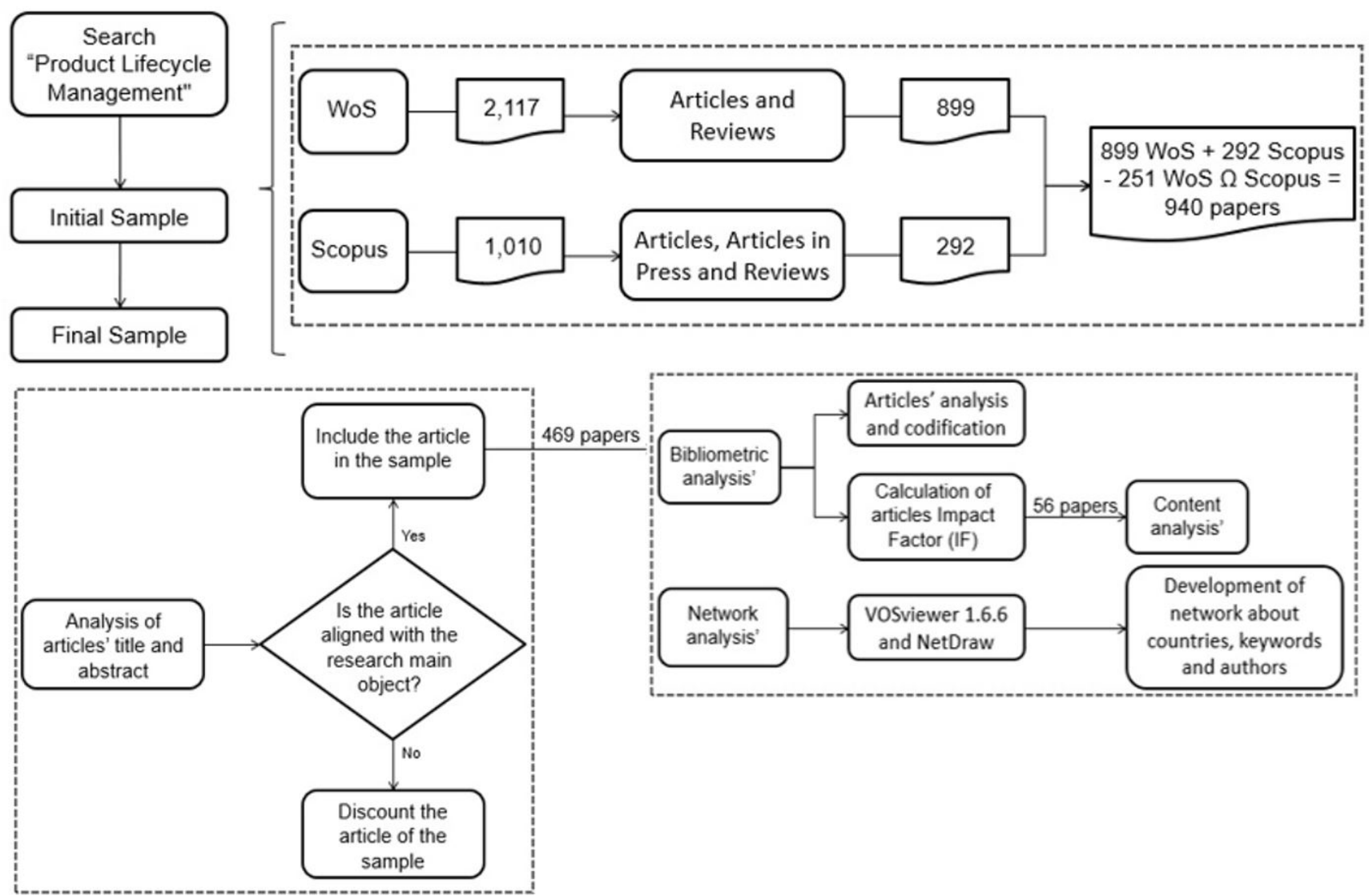

Figure 1. Systematic literature review workflow. 
scheme involving the publication methods and main subject. The third step consists of the network's development, using the VOSviewer 1.6.6 software to elaborate and to visualize the networks and the NetDraw software to edit the networks, analyzing all the publications, developing three networks: co-authorship countries, co-occurrence keywords, and citation authors. The fourth step, the database for the qualitative analysis were developed; for that, the papers' Impact Factor (IF) was calculated, using Equation 1, as in Carvalho et al. (2013). Pareto's analysis from Takey \& Carvalho (2016) was used to select the papers representing an $80 \%$ IF, resulting in 56 publications, composing this study content analysis.

$$
I F=C *(J C R+1)
$$

Equation 1. Impact Factor (IF).

$\mathrm{C}$ - represents the number of citations and JCR - the impact factor of the journal in which the paper was published, based on its Journal Citation Report. Source: Carvalho et al. (2013).

\section{Results}

The results of this research were classified into two main categories, quantitative results and qualitative results.

\subsection{Quantitative results}

This section presents the quantitative results of this research, divided into two groups, bibliometrics and networks results.

\subsubsection{Bibliometrics results}

Analyzing the publications, it is possible to evidence 469 papers meeting to this study interest, in an evolution along the years evidenced in Figure 2, with the number of accumulated publications increasing along the analyzed years (2001-2018), since the first publication in the theme of interest.

This evidenced that the main journals publishing in the subject were Computers in Industry (8\%), International Journal of Product Lifecycle Management (5\%) and Concurrent Engineering Research and Applications (4\%). The other journals have a representatively inferior to $3 \%$, being a subject of interest from different journals.

\subsubsection{Networks results}

Out of 56 different countries, 21 countries presented a minimum of five documents published; the co-authorship countries network evidences the countries publishing together, see Figure 3.

The main connections are between France and the United Kingdom; France and Switzerland; Germany and the United States of America; and China and Singapore. Only four countries represent $53 \%$ of the citations and $51 \%$ of the publications number, respectively, the United States of America $(20 \% ; 13 \%)$, China $(13 \% ; 14 \%)$, the United Kingdom $(11 \% ; 10 \%)$ and France $(10 \% ; 14 \%)$.

There are 3,194 different keywords, 31 keywords have a minimum of 17 occurrences, leading a three main clusters, see Figure 4.

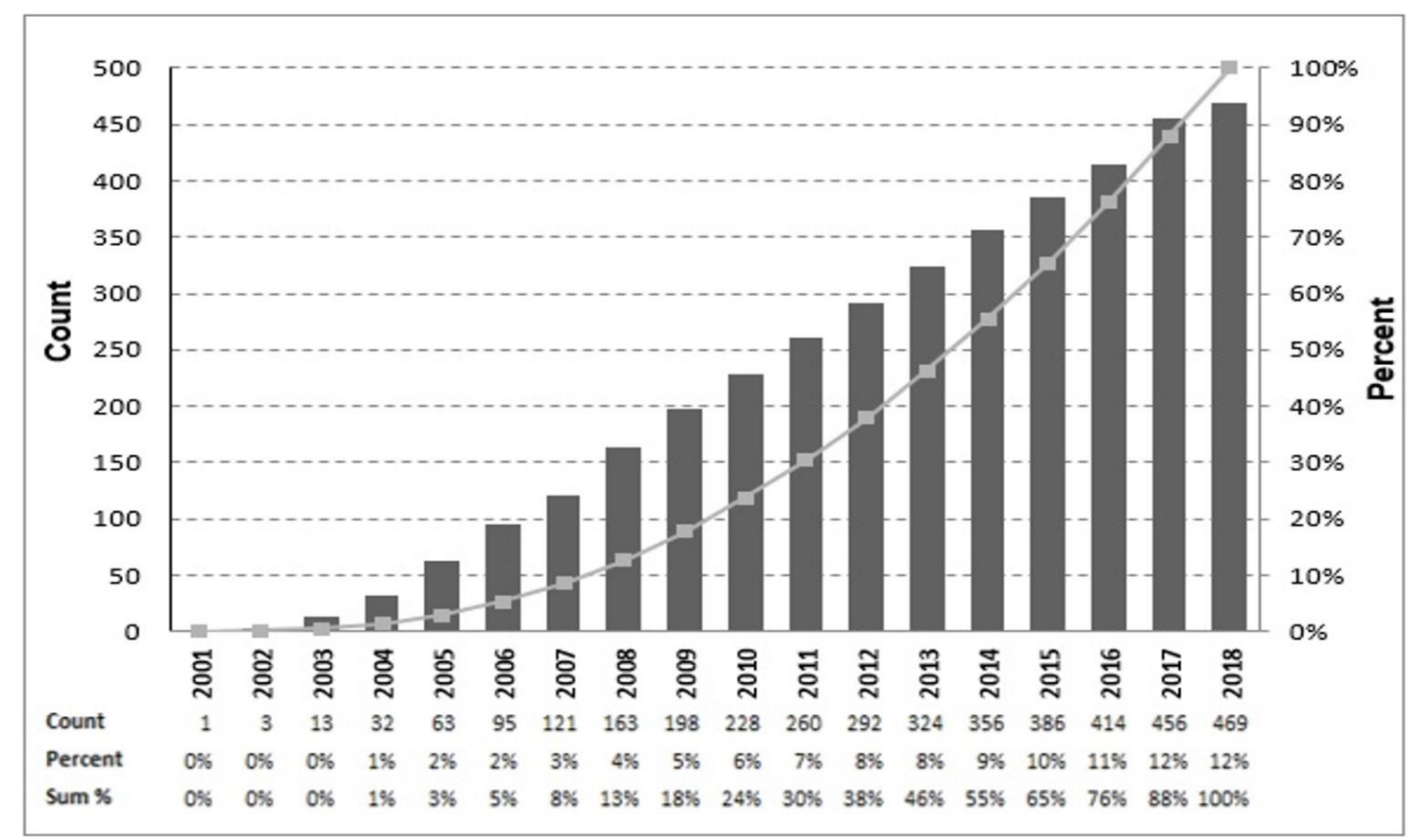

Figure 2. Accumulated view of the publications, evolution along the years. 


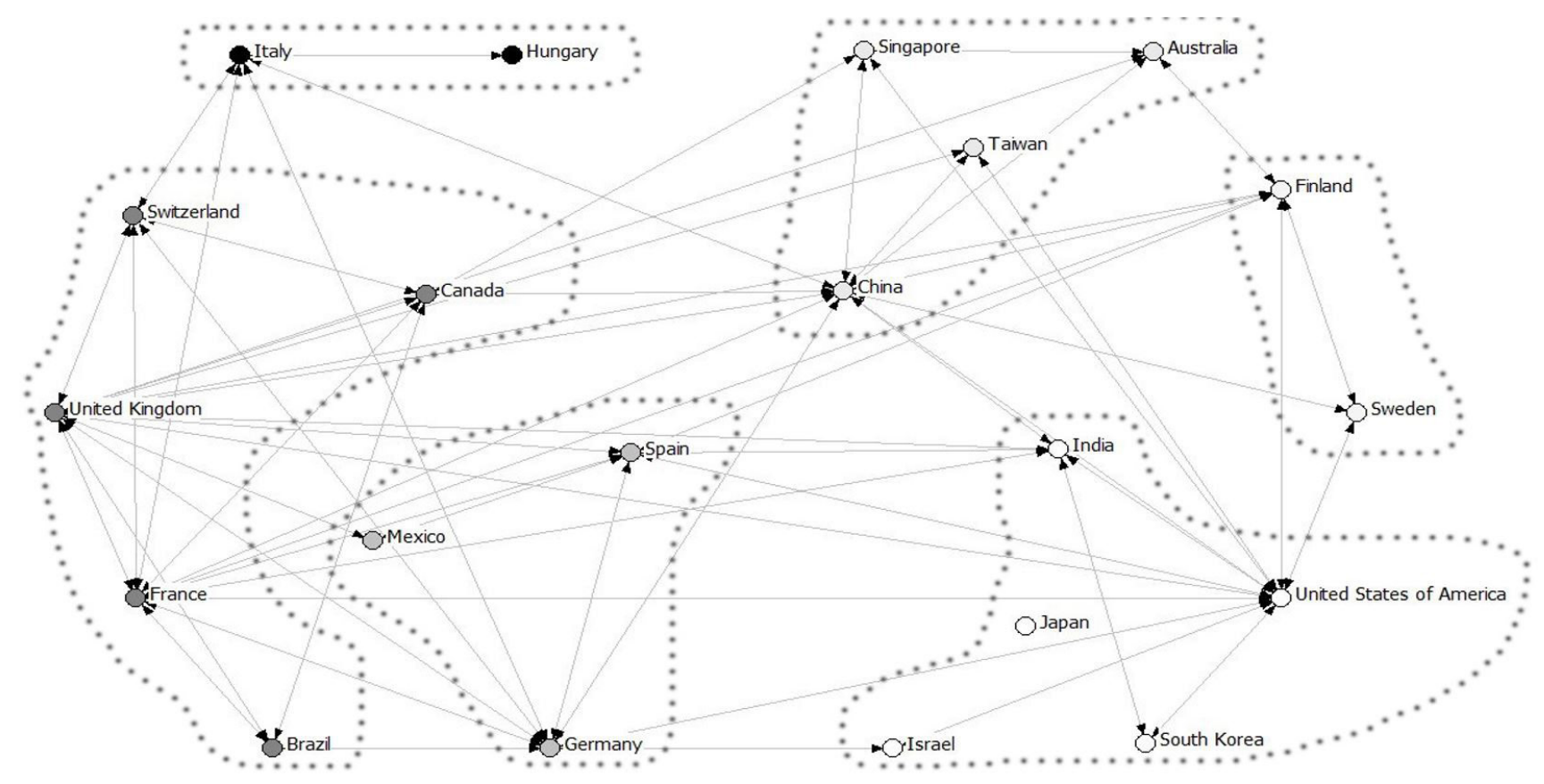

Figure 3. Co-authorship countries network.

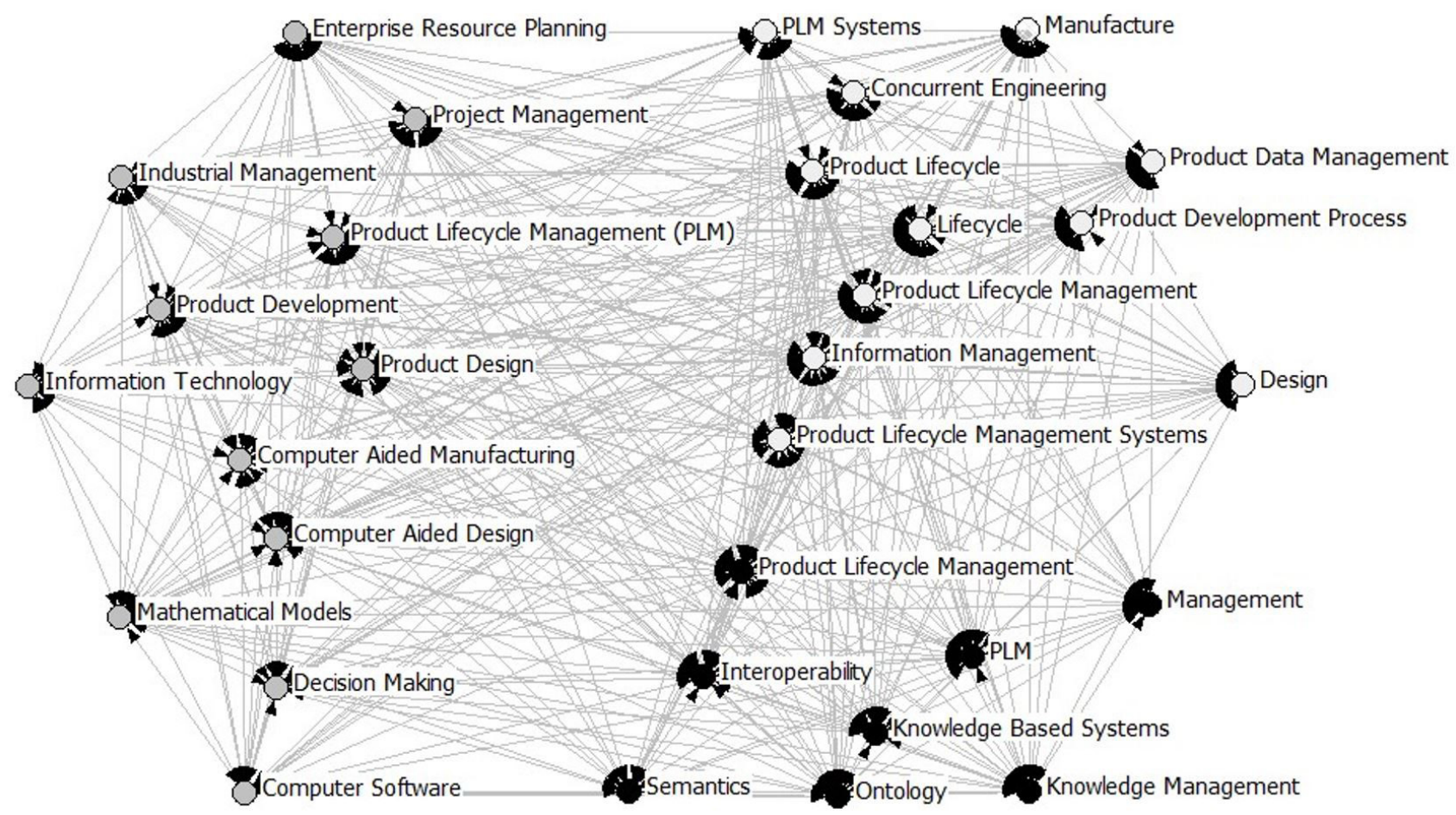

Figure 4. Co-occurrence keywords network.

The major clusters were Management, Development and Systems, the pillars of currently concept of PLM. The main connections are between Product Lifecycle Management and Lifecycle; Product Lifecycle Management and Product Design; Lifecycle and Product Lifecycle Management; and Lifecycle and Product Development. Only five keywords represented $51 \%$ of the occurrences, Product Lifecycle Management (20\%), Lifecycle (15\%), Product Development (9\%) and Product Design (7\%).

Out of 1,074 different authors, only 16 authors present a minimum of five publications; forming five main clusters, see Figure 5. 


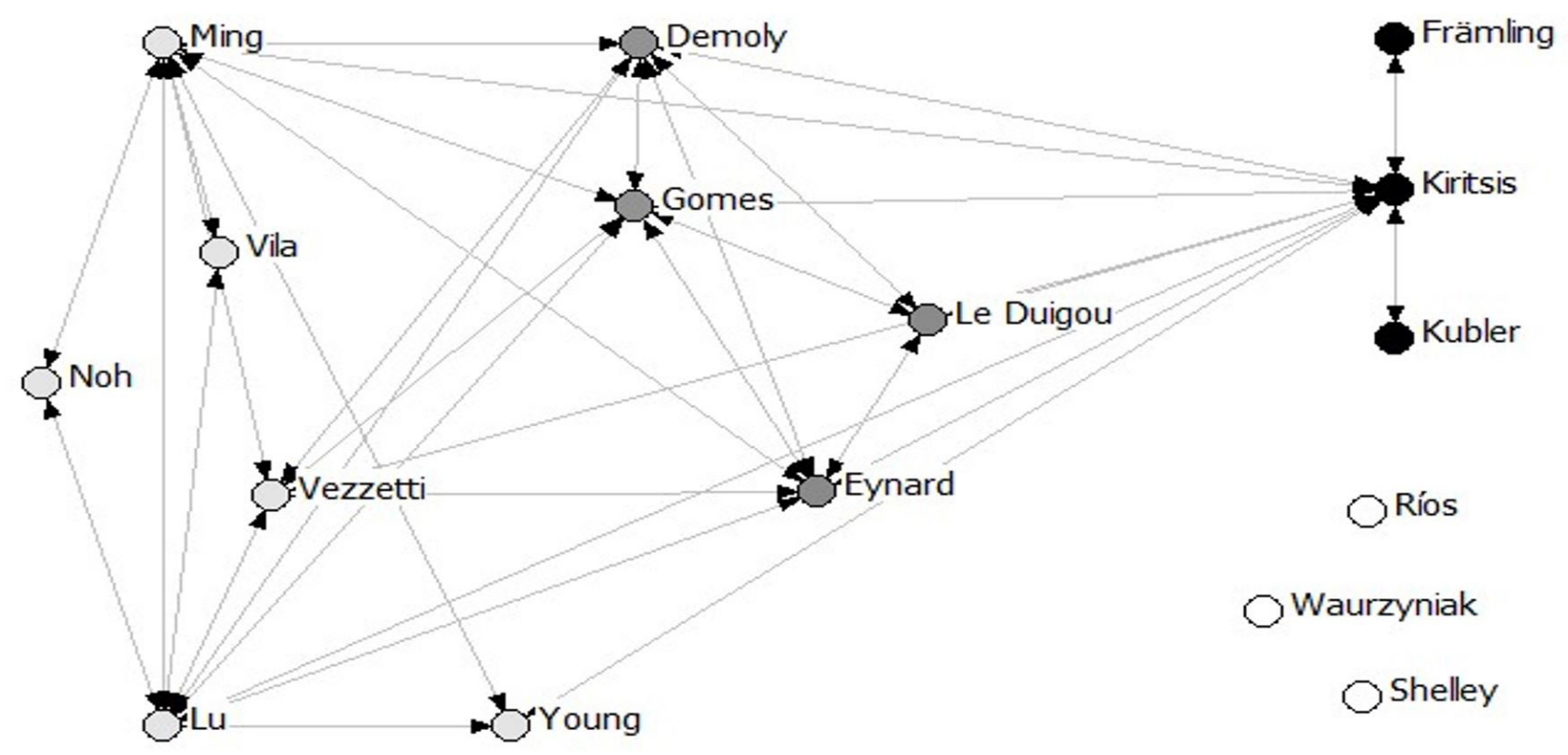

Figure 5. Citation authors network.

Only three authors represented $51 \%$ of the citations, detailing, Kiritsis (32\%), Eynard (10\%) and Vezzetti (9\%). The main connections are between Demoly and Gomes; Demoly and Kiritsis; Demoly and Eynard; and Kiritsis and Eynard. Evidencing only few authors publishing about the theme.

\subsection{Qualitative results}

This section presents these research qualitative results, presenting the contents analysis, which can also be considered as the literature review of this study.

\subsubsection{PLM evolution and concept}

The concept of Product Lifecycle Management (PLM) appeared in the 90s as an extension of Product Data Management (PDM) (Stark, 2011), providing more information related to large organizations (Kiritsis, 2011). The PDM has been developed to improve the data management and documented knowledge for new products design, allowing the focus on the product design and production phases (Kiritsis, 2011). In this view, PLM development depended upon the idea of an evolution and continual assimilation of computer-oriented product-based solutions, from early engineering design applications (e.g. Computer-Aided Design (CAD) or Computer-Aided Manufacturing (CAM)) in the 70 s and 80 s, through to the integration of Enterprise Resource Planning (ERP), Customer Relationship Management (CRM) and Supply Chain Management (SCM) solutions (Ameri \& Dutta 2005). The importance of product information management during the whole product lifecycle has increased due to the technical sophistication of products as well as stricter governmental regulations for lifecycle management (Främling et al., 2006).

PLM concept provides a definition of a complete product lifecycle, including all information and processes required to plan, develop, manufacture and support the product from conception through the end of its lifecycle, integrating: people, processes, business systems and information (Lee et al., 2008a). Appearing to focus on a design perspective with the best association with the manufacture components parts (Young et al., 2007). This concept evidence the importance of a manufacturing model that not only provides a common information source to support design decisions, but which focus in the business core competencies, providing a new understanding of the product manufacturer, with a model that can be updated for future benefits (Young et al., 2007).

As benefits, the PLM is a strategic business system that allows effective communication among different groups at dispersed locations, to share ideas and access information, to develop new products and execute innovative processes (Lee et al., 2008a). In summary, PLM not only provide process management throughout the entire product lifecycle, but also enables effective collaboration among networked participants in product value chain, which distinguishes it from other enterprise application systems, such as Enterprise Resource Planning (ERP), Supply Chain Management (SCM), Customer Relationship Management (CRM), etc. (Ming et al., 2008). With the goal of reducing the product time to market improving the product functionality and increasing the ability to customize (Schuh et al., 2008). Under these circumstances, new PLM system development 
technologies are being employed to develop attractive PLM systems that will provide more satisfaction to customers (Schuh et al., 2008).

In the literature review, several different PLM definitions were found, summarized in the Table 1.

\subsubsection{PLM in the products' lifecycle}

The product lifecycle consists of three main phases:

- Beginning-Of-Life (BOL): including design and manufacture;

- Middle-Of-Life (MOL): including use, service, maintenance, and distribution (logistics);

- End-Of-Life (EOL): where products are recollected, disassembled, remanufactured, recycled, reused, or disposed.

During BOL, information flow is quite complete and supported by information systems such as Computer Aided Design (CAD)/Computer Aided Manufacture (CAM), Product Data Management (PDM) and Knowledge Management systems (Jun et al., 2009; Cao \& Folan, 2011;
Kiritsis, 2011; Cao et al., 2009). However, the information flow becomes vague or unrecognized after BOL, demanding the feedbacks of product-related information such as product usage data, and disposal conditions to have information supporting the MOL and EOL phases (Jun et al., 2007). In a scenario where the lifecycle activities of MOL and EOL phases have limited visibility of the product-related information (Jun et al., 2007), emerging the PLM to allow the management of product lifecycle data, offering the features present in Figure 6.

Detailing the PLM system, they are generally computerbased information systems which assist the organization's PLM strategy. The components in a full PLM system include the items evidenced in Figure 7.

The idea is that information of MOL could be used at the EOL to support deciding the most appropriate EOL option (specially to plan for re-manufacturing and reuse), providing feedback for the BOL, improving a new generation of products (Demoly et al., 2012).

All these phases have as objective to minimize cost and time by understanding problems before the product development and manufacturing processes, improving the

Table 1. PLM definitions.

\begin{tabular}{|c|c|}
\hline Author & Definition \\
\hline Sharma (2005) & $\begin{array}{l}\text { A concept that aims to integrate the various processes and phases involved during a typical product lifecycle. } \\
\text { Based on horizontal business processes without a single tool or a package that can describe the whole PLM. }\end{array}$ \\
\hline Jun et al. (2007) & $\begin{array}{l}\text { A new strategic approach to manage the product lifecycle information efficiently. Enabling to gather and analyze } \\
\text { the product lifecycle information and make decisions on several issues. }\end{array}$ \\
\hline Chen et al. (2008) & A strategic business approach that manage all the product lifecycle stages. \\
\hline Lee et al. (2008a) & A concept that evidence the information management, throughout all the stages of a products' lifecycle. \\
\hline Ming et al. (2008) & $\begin{array}{l}\text { New strategic business model to support collaborative creation, management, dissemination, and use of product } \\
\text { assets, including data, information, knowledge, etc. Assist organizations in conceptualizing end of life, integrating } \\
\text { people, processes and technology. }\end{array}$ \\
\hline Rachuri et al. (2008) & $\begin{array}{l}\text { A strategic approach to create and manage the organization's intellectual capital, from the since a product initial } \\
\text { conception until its discontinuity of production. Supports the product lifecycle by modeling, capturing, manipulating } \\
\text { and exchanging the information. }\end{array}$ \\
\hline Alemanni et al. (2010) & $\begin{array}{l}\text { An extension of Product Data Management (PDM), representing the missing link between Computer Aided Design } \\
\text { (CAD), digital manufacturing, and simulation. Representing the virtual world and interfaces with the Enterprise } \\
\text { Resource Planning (ERP) system supporting the physical side of modern manufacturing along the supply chain. }\end{array}$ \\
\hline Kiritsis (2011) & $\begin{array}{l}\text { Strategical approach with three fundamental dimensions: (i) universal, secure, managed access and use of product } \\
\text { definition information, (ii) maintaining the integrity of the product definition, being related with information } \\
\text { throughout the life of the product or plant and (iii) managing and maintaining business processes used to create, } \\
\text { manage, disseminate, share and use of information. }\end{array}$ \\
\hline Marchetta et al. (2011) & A key concept for manufacturing industries to improve product quality, time-to-market and costs. \\
\hline Al-Ashaab et al. (2012) & $\begin{array}{l}\text { Strategy and technique that assist the organizations to succeed in the manufacturing industry. Assisting to maintain } \\
\text { the product data timeliness, validity, accuracy, and traceability. }\end{array}$ \\
\hline Kubler et al. (2015a) & $\begin{array}{l}\text { A wide-ranging concept that aim to integrate the product lifecycle, including people, data, products, processes, } \\
\text { metrics and so forth. }\end{array}$ \\
\hline Zhao et al. (2015) & $\begin{array}{l}\text { Integrated management of relevant information throughout the product lifecycle from customer needs capture, } \\
\text { through product design and engineering, manufacturing, maintenance, and service, to market. }\end{array}$ \\
\hline Bonou et al. (2016) & $\begin{array}{l}\text { Is the overarching process for all the product development activities. Including the customer-oriented strategic } \\
\text { planning, design, and development, monitoring the whole product lifecycle activities. }\end{array}$ \\
\hline Soto-Acosta et al. (2016) & $\begin{array}{l}\text { A new approach for management information along the product lifecycle, enabling organizations to reduce } \\
\text { products' time to market as well as to respond to a growing demand for quality and customization of products. }\end{array}$ \\
\hline
\end{tabular}


Centralize, controll and

manipulate the lifecycle

data related to the after-

sales service (MOL), and

product retirement process

(EOL) as well as the

previous design and

manufacturing phases

(BOL).
Share this lifecycle data

with all stakeholders by

means of web-based or

webenabled technology.
Transforme the lifecycle

data into a structured

knowledge form that can be

retrieved, represented and

reused easily and

efficiently, by many

organizations in the

extended enterprise, and

throughout the whole

product lifecycle.

Figure 6. Features obtained by PLM for product lifecycle data management. Source: Adapted from Cao et al. (2009).
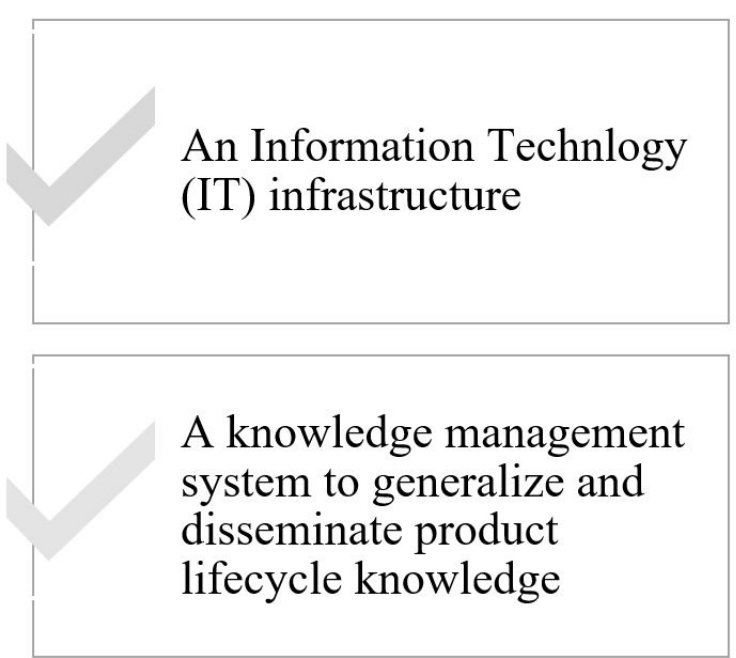

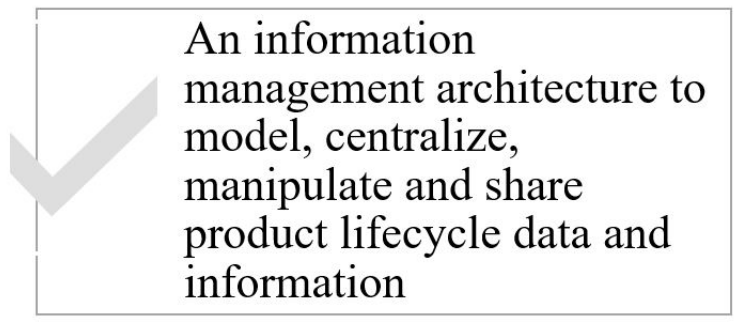

A set of business applications to support the utilization of lifecycle data and knowledge, in various organizations and different lifecycle stages

Figure 7. PLM system components.

Source: Adapted from Cao et al. (2009).

organization's performance utilizing technology and support (Soto-Acosta et al., 2016). Around $40 \%$ of engineer's time is spent to connect the information about the processes, with information search and sharing, and in this scenario, the correct usage of PLM can save at least $50 \%$ of this time, which could be used to develop more value-adding tasks (Soto-Acosta et al., 2016).

PLM offers a range of tools to support the business, including the ability to manage workflows, but the heart of an effective PLM system is the database structuration, ensuring that all users have access to effective information support (Young et al., 2007). Companies need to connect the product design and analysis processes to the production and supply chain processes with PLM support, including: Product Data Management (PDM), Component Supplier Management (CSM), Enterprise Resource Planning (ERP), Manufacturing Execution Systems (MES), Customer Relationship Management (CRM), Supply and Planning Management (SPM), and others (Rachuri et al., 2008). Occurring the PLM optimization achievement only when the knowledge sharing happens in the whole product lifecycle, with the PLM development being the result of integrating many lifecycle data (Zhang et al., 2017a).

Still on PLM in the product's life cycle, some relevant improvement opportunities emerge, evidenced in Figure 8. 
Traceability and data synchronization (Kubler et al., 2015b).

Lack of attention to customer requirements, happing problems in terms of design ability, delays due to incomplete designs, rework because of customer misunderstandings expectations, etc. (Lee et al., 2008b).

The ability to share information across competitive software tools are limited, with the development of information systems tend inflexible to change and the ability to share diverse views of similar information needed by teams of engineers cannot yet be supported (Young et al, 2007).

Limitations of commercial PLM software (Soto-Acosta et al., 2016).

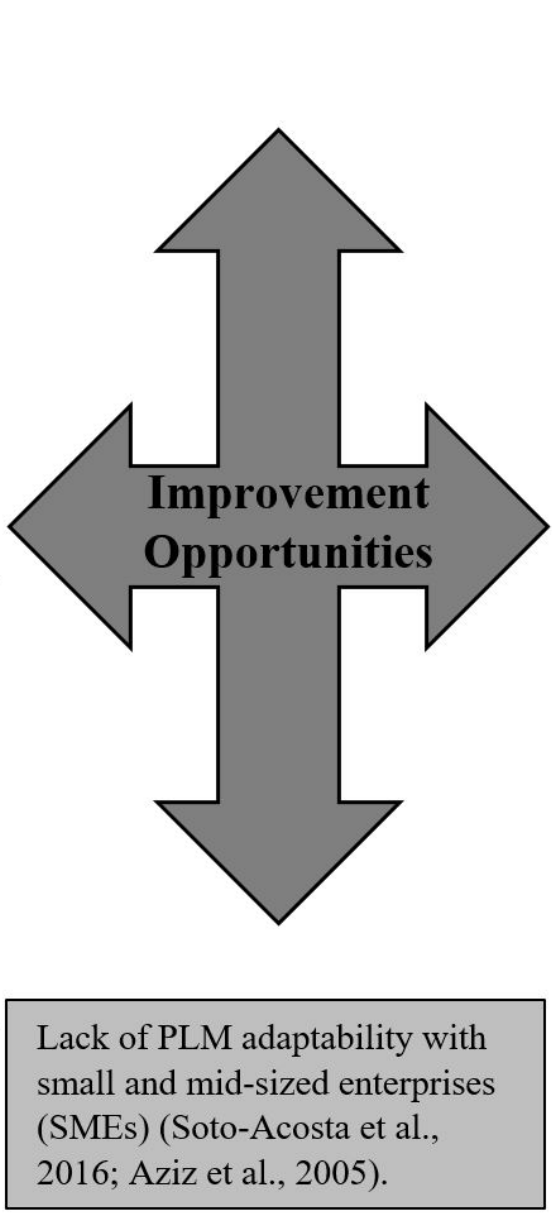

Problems of interoperability and data integration (Matsokis \&

Kiritsis. 2010).

Compatibility issues (Demoly et al.. 2013).

Customization for sustainability (Främling et al., 2013).

Standardize product meta data models (Srinivasan, 2011).

Need for capacity building in life cycle thinking and concerns, with the PLM complexity iterations and the need for integration and training, during implementation. (Bonou et al., 2016).

More data sources and relations require more interfaces, meaning more points of potential failure (Alemanni et al., 2010).

Figure 8. Improvement opportunities

Opportunities which can be seeen as gaps/needs that can be filled in with the improvement of PLM.

\subsubsection{PLM applications}

A big challenge is to understand the implications of developing and interoperating across different types of knowledge environments and product lifecycle systems (Chungoora et al., 2013). Thereby, there is a tendency in converting existing models into ontologies and the creation of new models, and because of this in the PLM field, there are several recent works dealing with ontologies (Matsokis \& Kiritsis, 2010). Besides that, the past years have presenting growing investments in the field of PLM, by the automotive sector and the manufacturing industry, that is facing tremendous pressure on environmental regulations, such as the reduction of pollutants, e.g., carbon dioxide (Tang \& Qian, 2008).

In this scenario, the researchers classified the application fields according to the number of published papers, $68 \%$ of the publications are from the application areas shown in Figure 9 and the other $32 \%$ of the articles are from application areas that have less than $1 \%$ of representativeness on the PLM topic which can be seen by the author in Appendix 1.

Besides that, the articles were separated by subject, see Figure 10, evidencing the most published articles on the topic are related to systems from which it can be connected and used in conjunction with PLM.

The more representative keywords can be visualized in Figure 11, and the detailing with the authors are in Appendix 2.

\subsubsection{PLM implementation}

When a company adopts PLM for the first time, the implementation process itself becomes a process of change (Soto-Acosta et al., 2016). This is because these changes should occur not only at the IT level but also at strategic and process level, more specifically, at the level of the individual skills and capabilities of employees (Soto-Acosta et al., 2016). With the PLM being currently a technological solution for a system with a high number and variety of information systems that need to communicate over organizational limits and overtime (Främling et al., 2013). 


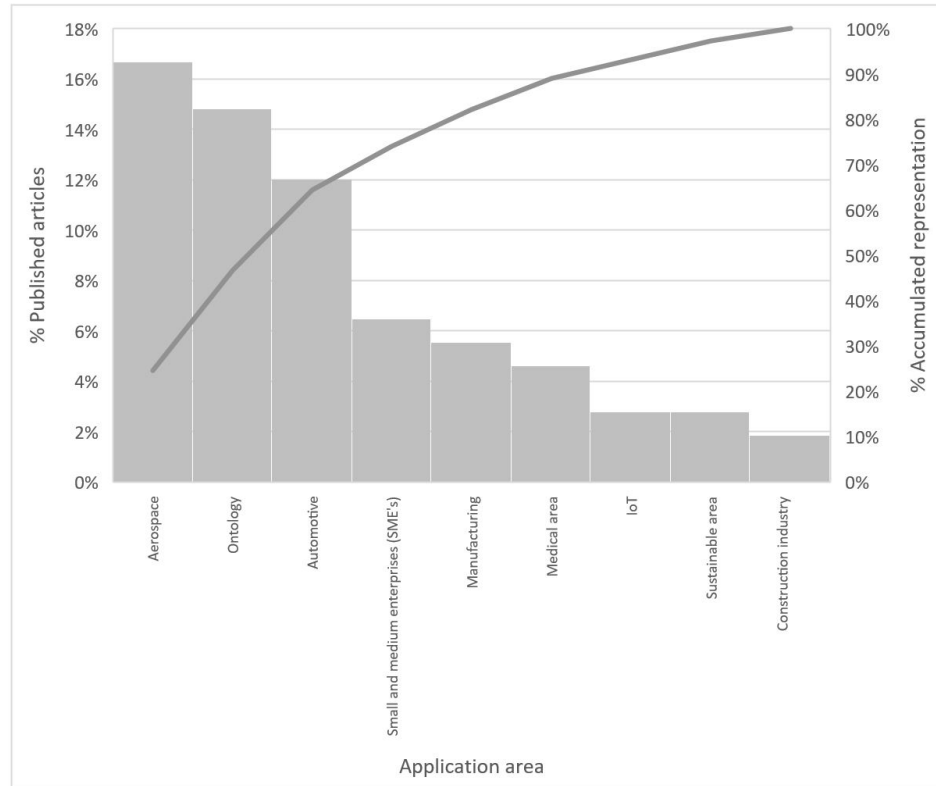

Figure 9. Representativeness of the most relevant application areas x Published articles

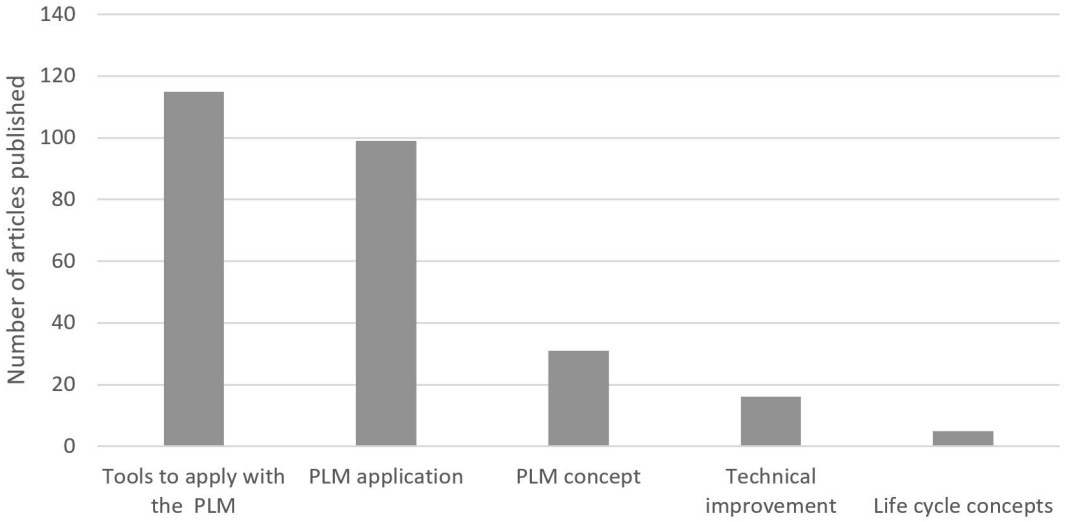

Figure 10. Number of articles published x Subject article.

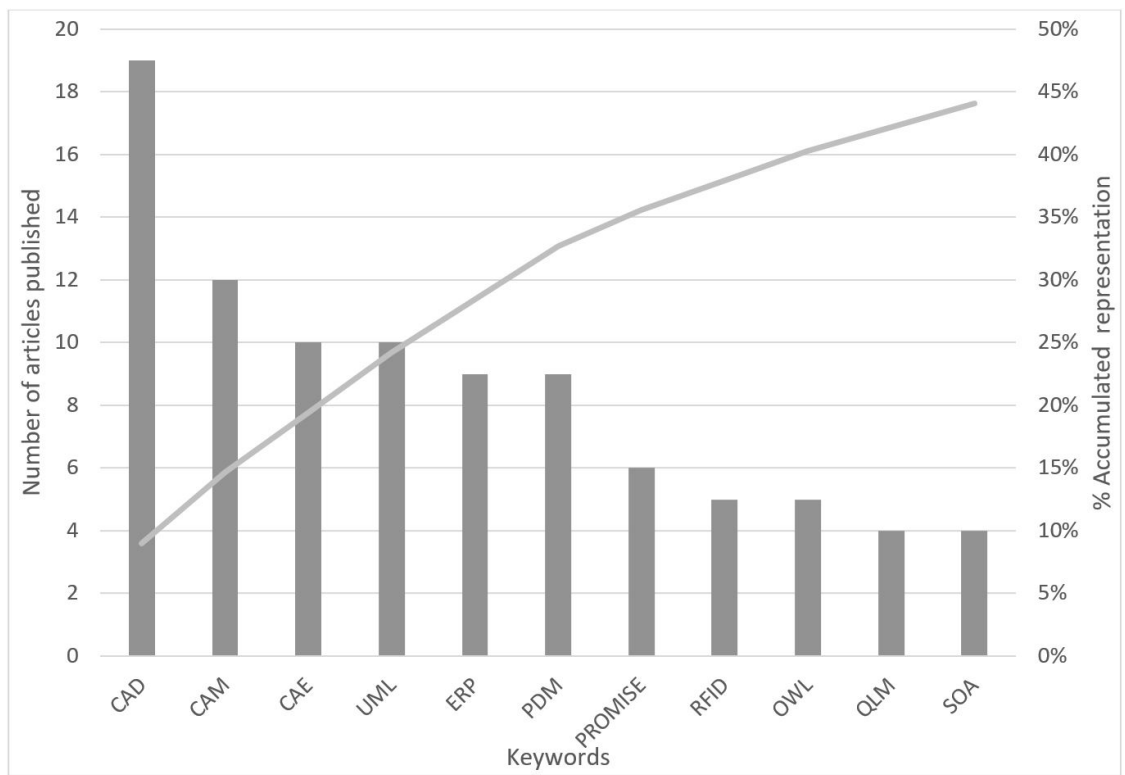

Figure 11. Keywords x Articles published. 
Companies aiming to implement PLM can refer to the provided conceptual framework to establish their own framework, linking the company elements in a comprehensive PLM environment (Schuh et al., 2008). Therefore, the following ten steps are necessary: define the goal of PLM implementation; analyze the existent PLM foundation; rank processes; identify company maturity level (as-is process); select an appropriate reference model; customize reference model; specify requirements for system selection; select software solution; define the evolution path; implement software solution; and teach employees (Schuh et al., 2008). Besides the fact that the implementation of PLM strategy is a very long-period investment and the benefits are not measurable in a short period.

PLM implementation failures in cases of incompatibly between the selected software and the company philosophy (Soto-Acosta et al., 2016). In order to avoid this type of issue, the choice of the PLM solution must be preceded by an extensive analysis of business processes and procedures (Soto-Acosta et al., 2016), and ever-stricter environmental legislation over the past decade has led to the search for greater efficiencies everywhere, including the whole product lifecycle (Cao et al., 2009).

Although the potential of closed-loop PLM is widely recognized and have started to address its challenge, there are still fundamental questions and issues that need to be addressed. (Främling et al., 2014). There are limitations of commercial PLM software which means that adopting commercial PLM software implies assuming certain limitations since the beginning. For instance, the integration of the PLM with other systems (Soto-Acosta et al., 2016). It's necessary to manage a set of relations to provide consistency of data spread across different media and formats, sometimes referred to as "associativity" (Alemanni et al., 2010) and, there is also opportunity for improvement at architectures which tend to be inflexible at data interface (Främling et al. 2014; Young et al., 2007), meaning more points of potential failure (Alemanni et al., 2010). Also, it's necessary to improve the traceability and data synchronization (Kubler et al., 2015a), and the ability to share information across competitive software tools (Young et al., 2007).

\section{Discussion}

The main objective of the article is to understand how the concept of PLM was approached in the academy. The article presents the main approaches on the subject aiming to give a comprehensive view of the researches already done and gaps in studies that can be focused in future researches.

With this study, it is possible to show that among the articles studied there are more studies approaching only the applications of the system in few areas or studies that are focused in PLM applications in conjunction with other tools. Another discovery was that the three most advanced areas are Ontology, Automotive, and Manufacturing. Areas such as Oil and Gas, Healthcare and Food Industry have a high potential for the development of application of PLM.

The co-occurrence keywords evidenced the keyword Product Lifecycle Management in all clusters, but being evidenced as the abbreviation PLM only in one cluster, more related to product development and information technology with mathematical models. The bibliographical research evidence that the published articles are centralized in some journals and in a few countries.

In a highly competitive and fast-changing global marketplace, PLM is a new strategic approach to efficient management, its concept is composed of the following steps: beginning-of-life, middle-of-life and end-of-life, which includes the design and the manufacture until the recycle, reuse and disposing of the product. Therefore, the PLM enables to gather and analyze the product lifecycle information, which means that it is a key approach for industries who are searching to improve product quality, time-to-market and costs.

The article also has the PLM implementation perspective. It becomes as a process of change, that presents opportunities for improvement at architectures, and requires a high company maturity level to the software implementation. However, it is possible to admit that the concept of PLM is evolving and has already brought benefits, but still demand more specific case studies to better evidence the theoretical studies about the relevance of the system, the stages of the cycle, the results of system implementation and the best practices for the ones who participate of the implementation and for those who receive this change in their process.

\section{Conclusion}

This paper has provided an overview of PLM state of the art. The PLM was described through PLM justification; goals; concept; applications and implementation showing the benefits and the gaps for all steps. Thereby, the study brings into view of the main authors and their approaches to the theme with different and complementary views of the concept. Besides that, it can also show the difficulties found by them during their studies.

Thus, for future researchers, it is important to understand these difficulties and to explore these points and other elements such as PLM applications with real cases studies. Mainly with application in the strategical decision making; more management indicators that involve PLM; to include semantic, heuristics and mathematical models; to explore the data synchronization mechanisms; reinforce the connection and the challenges between the PLM, the big data, and the IoT. Exploring also the communication, the intelligent products and the integration between them with the objective of reducing environmental impacts and 
applying all these studies with the goal to explore in ClosedLoop Lifecycle Management (CL2M) as well.

In conclusion, with this, PLM is a complex concept and there is a lack of a deep understanding of the real potential of its application. And there is also a need to have more studies with more integration between all the parts that integrate it through real applications. With this article having as limitations the fact that only used the Scopus and WoS databases, and some figures and analysis were developed only for the papers that compose the contents analysis.

\section{References}

Abid, H., Pernelle, P., Noterman, D., Campagne, J., \& Ben Amar, C. (2014). SysML approach for the integration of a mechatronics system within PLM systems. International Journal of Computer Integrated Manufacturing, 28(9), 972-998.

Adami-Sampson, M. (2007). Design for environmental compliance. Control Engineering, 54(2), 12-14.

Al-Ashaab, A., Molyneaux, M., Doultsinou, A., Brunner, B., Martínez, E., Moliner, F., Santamaría, V., Tanjore, D., Ewers, P., \& Knight, G. (2012). Knowledge-based environment to support product design validation. Knowledge-Based Systems, 26, 48-60.

Alemanni, M., Alessia, G., Tornincasa, S., \& Vezzetti, E. (2008). Key performance indicators for PLM benefits evaluation: the Alcatel Alenia Space case study. Computers in Industry, 59(8), 833-841.

Alemanni, M., Destefanis, F., \& Vezzetti, E. (2010). Modelbased definition design in the product lifecycle management scenario. International Journal of Advanced Manufacturing Technology, 52(1-4), 1-14.

Alison, W. (2010). Controlling the lifecycle. Drapers, 26-27.

Allanic, M., Durupt, A., Eynard, B., Allanic, M., Joliot, M., Allanic, M., Brial, T., \& Boutinaud, P. (2014). Towards enhancement of relationships browsing in mature PLM systems. IFIP Advances in Information and Communication Technology, 422(1), 345-354.

Allen, D. G., Hancock, J. I., Vardaman, J. M., \& Mckee, D. N. (2014). Analytical mindsets in turnover research. Journal of Organizational Behavior, 35, 61-86.

Ameri, F., \& Dutta, D. (2005). Product lifecycle management: closing the knowledge loops. Computer-Aided Design and Applications, 2(5), 577-590.

Anderson, A. (2002). From product first to better products. Msi, 20(10), 2A-8A.

Anišić, Z., Veža, I., Suzić, N., Sremčev, N., \& Tekic, A. (2013). Improving product design with IPS-DFX methodology incorporated in PLM software. Tehnicki Vjesnik (Strojarski Fakultet), 20(1), 183-193.
Arslan, D. (2012). Examining first-grade teachers' handwriting instruction. Educational Sciences: Theory and Practice, 12(4), 2839-2846.

Avventuroso, G., Silvestri, M., \& Pedrazzoli, P. (2017). A networked production system to implement virtual enterprise and Product Lifecycle information loops. Ifacpapersonline, 50(1), 7964-7969.

Aziz, H., Gao, J., Maropoulos, P., \& Cheung, W. M. (2005). Open standard, open source and peer-to-peer tools and methods for collaborative product development. Computers in Industry, 56(3), 260-271.

Bartholomew, D. (2004). The juice flows again. Industry Week, 253(3), 31-34.

Bartholomew, D. (2005). Manufacturers nibbling on PLM. Industry Week, 254(4), 63-64.

Barthorpe, S., Chien, H. J., \& Jack, K. C. S. (2004). A survey of the potential for enterprise resource planning (ERP) in improving the effectiveness of construction management in the UK construction industry. International Journal of Computer Applications in Technology, 20(1-3), 120-128.

Baughey, K. (2009). The future of automotive design \& amp; development: 3D for all. SAE International Journal of Materials and Manufacturing, 2(1), 258-264.

Bonou, A., Skelton, K., \& Olsen, S. I. (2016). Ecodesign framework for developing wind turbines. Journal of Cleaner Production, 126, 643-653.

Borsato, M. (2014). Bridging the gap between product lifecycle management and sustainability in manufacturing through ontology building. Computers in Industry, 65(2), 258-269.

Borsato, M., Estorilio, C. C. A., Cziulik, C., Ugaya, C. M. L., \& Rozenfeld, H. (2010). An ontology building approach for knowledge sharing in product lifecycle management. International Journal of Business and Systems Research, 4(3), 278-292.

Brezgin, V. I., Brodov, Y. M., Chubarov, A. A., \& Brezgin, D. V. (2013). Modern technologies for rendering information support to cogeneration steam turbine units in their design and operation stages. Thermal Engineering, 60(8), 573-579.

Brière-Côté, A., Rivest, L., \& Desrochers, A. (2010). Adaptive generic product structure modeling for design reuse in engineer-to-order products. Computers in Industry, 61(1), 53-65.

Brincheck, B. (2005). End-to-end 3-D PLM puts 2-D in its proper place. Design Engineering (London), 51(6), 26-28.

Bruno, G., Korf, R., Lentes, J., \& Zimmermann, N. (2016). Efficient management of product lifecycle information through a semantic platform. International Journal of Product Lifecycle Management, 9(1), 45-64. 
Brunsmann, J., Wilkes, W., Schlageter, G., \& Hemmje, M. (2012). State-of-the-art of long-term preservation in product lifecycle management. International Journal on Digital Libraries, 12(1), 27-39.

Bruun, H. P. L., Mortensen, N. H., Harlou, U., Wörösch, M., \& Proschowsky, M. (2015). PLM system support for modular product development. Computers in Industry, 67, 97-111.

Cáceres, M. S., Castillo, R. A., \& Rosário, J. M. (2010). Digital manufacturing - Integration and collaborative industrial automation approach. International Review of Mechanical Engineering, 4(3), 336-345.

Cai, H., Xu, L., \& Xu, B. (2014). IoT-Based configurable information service platform for Product Lifecycle Management. IEEE Transactions on Industrial Informatics, 10(2), 1558-1567.

Camarillo, A., Ríos, J., \& Althoff, K. (2018). Knowledge-based multi-agent system for manufacturing problem solving process in production plants. Journal of Manufacturing Systems, 47, 115-127.

Camarillo, A., Ríos, J., \& Althoff, K. D. (2017). CBR and PLM applied to diagnosis and technical support during problem solving in the Continuous Improvement Process of manufacturing plants. Procedia Manufacturing, 13, 987-994.

Cantamessa, M., Montagna, F., \& Neirotti, P. (2012). Understanding the organizational impact of PLM systems: evidence from an aerospace company. International Journal of Operations \& Production Management, 32(2), 191-215.

Cao, H., \& Folan, P. (2011). Product life cycle: the evolution of a paradigm and literature review from 1950-2009. Production Planning and Control, 23(8), 641-662.

Cao, H., Folan, P., Mascolo, J., \& Browne, J. (2009). RFID in product lifecycle management: a case in the automotive industry. International Journal of Computer Integrated Manufacturing, 22(7), 616-637.

Caro, E., Bolarin, F., \& Chocano, J. (2011). Mejora del desarrollo de productos desde la perspectiva de gestión del conocimiento. Dyna Ingenieria e Industria, 86(3), 699-706.

Carvalho, M. M., Fleury, A., \& Lopes, A. P. (2013). An overview of the literature on technology roadmapping (TRM): contributions and trends. Technological Forecasting and Social Change, 80(7), 1418-1437.

Case, L. (2006). Solution built on UGS' teamcenter software drives dramatic cost savings for industries managing embedded software associated with electro-mechanical systems. Automotive Industries Ai, 186(4), 7.

Chen, H. H., Kang, H.-Y., Xing, X., Lee, A. H. I., \& Tong, Y. (2008). Developing new products with knowledge management methods and process development management in a network. Computers in Industry, 59(2-3), 242-253.
Chiappinelli, C. (2008). Lean + technology = lean2. Managing Automation, 23(12), 36-38.

Chungoora, N., Young, R. I., Gunendran, G., Palmer, C., Usman, Z., Anjum, N. A., Cutting-Decelle, A. F., Harding, J. A., \& Case, K. (2013). A model-driven ontology approach for manufacturing system interoperability and knowledge sharing. Computers in Industry, 64(4), 392-40.

Cole, M. D. (2009). PLM for C2M. Apparel, 50(6), 31-33.

Courtney, M. (2014). Keeping track [Product lifecycle management software]. Engineering \& Technology, 9(12), 64-66.

Crawford, C. (2006). O PLM or not to PLM? That is the question. AATCC Review, 6(9), 24-26.

Cui, J., Qi, G. N., Ji, Y. J., Gu, Q. X., Su, S. H., \& Hu, H. (2008). Customer requirement based on customer architecture hierarchy and BP in product lifecycle management system. Journal of Zhejiang University, 42(3), 528-533.

Cummings, T. (2006). Get your data in order. Control Engineering, 53(10)

D’Avolio, E., Bandinelli, R., \& Rinaldi, R. (2017). A processoriented framework for PLM implementation in fashion companies. International Journal of Product Lifecycle Management, 109(3), 191-209.

Demoly, F., Dutartre, O., Yan, X., Eynard, B., Kiritsis, D., \& Gomes, S. (2013). Product relationships management enabler for concurrent engineering and product lifecycle management. Computers in Industry, 64(7), 833-848.

Demoly, F., Matsokis, A., \& Kiritsis, D. (2012). A mereotopological product relationship description approach for assembly oriented design. Robotics and Computerintegrated Manufacturing, 28(6), 681-693.

Demoly, F., Monticolo, D., Eynard, B., Rivest, L., \& Gomes, S. (2010). Multiple viewpoint modeling frameworks enabling integrated product-process design. International Journal on Interactive Design and Manufacturing, 4(4), 269-280.

Demoly, F., Toussaint, L., Eynard, B., Kiritsis, D., \& Gomes, S. (2011b). Geometric skeleton computation enabling concurrent product engineering and assembly sequence planning. Computer Aided Design, 43(12), 1654-1673.

Demoly, F., Yan, X.-T., Eynard, B., Rivest, L., \& Gomes, S. (2011a). An assembly oriented design framework for product structure engineering and assembly sequence planning. Robotics and Computer-integrated Manufacturing, 27(1), 33-46.

Denkena, B., Shpitalni, M., Kowalski, P., Molcho, G., \& Zipori, Y. (2007). Knowledge management in process planning. CIRP Annals, 56(1), 175-180.

Dhuieb, M. A. (2014). Interoperability framework for supporting information-based assistance in the factory. IFIP 
Advances in Information and Communication Technology, 442(1), 201-310.

Dikici, A., Turetken, O., \& Demirors, O. (2018). Factors influencing the understandability of process models: A systematic literature review. Information and Software Technology, 93, 112-129.

Ding, L., Ball, A., Patel, M., Mullineux, G., \& Matthews, J. (2011). Lightweight product lifecycle information management for small enterprises. International Journal of Product Lifecycle Management, 5(1), 21-36.

Ducellier, G., Yvars, P., \& Eynard, B. (2014). Managing design change order in a PLM platform using a CSP approach. International Journal on Interactive Design and Manufacturing, 8(3), 151-158.

El Souri, M., Gao, J., Owodunni, O., Simmonds, C., \& Martin, N. (2017). A structured approach to defect data management for improving DFM implementation in aerospace manufacturing. International Journal of Product Lifecycle Management, 10(4), 282-300.

Essop, I. A., Evans, R. D., Wan, S., Giddaluru, M. P., Gao, J. X., Baudry, D., Mahdikhah, S., \& Messaadia, M. (2016). Investigation into current industrial practices relating to product lifecycle management in a multi-national manufacturing company. Computer-Aided Design and Applications, 13(5), 647-661.

Eynard, B., Troussier, N., \& Carratt, B. (2010). PLM-based certification process in aeronautics extended enterprise. International Journal of Manufacturing Technology and Management, 19(3-4), 312-329. http://dx.doi.org/10.1504/ ijmtm.2010.031376.

Falkiewicz, Ö. (2011). Electrical computer-aided engineering (E-CAE) software. Intech, Research Triangle, 58(3-4), 1-4.

Farish, M. (2008). Joined-up planning [product lifecycle management]. Engineering \& Technology, 3(21), 61-63.

Farish, M. (2012). Word on the street. Engineering (London), 253(2), 8-9.

Feng, Q., Ren, Y., Zeng, S.-K., \& Sun, B. (2009). Ontologybased multi-view modeling for integrated product development. Jisuanji Jicheng Zhizao Xitong, 15(4), 633638.

Feng, Q., Sun, B., Ren, Y., \& Zeng, S.-K. (2010). Modeling method for product comprehensive design process and its realization. Computer Integrated Manufacturing Systems CIMS, 16(4), 772-782.

Forcinio, H. (2007). Going green. Managing Automation, 22(4), 48-51.

Fortineau, V., Paviot, T., \& Lamouri, S. (2013). Improving the interoperability of industrial information systems with description logic-based models - The state of the art. Computers in Industry, 64(4), 363-375.

Fortineau, V., Talhi, A., Paviot, T., \& Lamouri, S. (2017). DALTON: a generic meta-model to support business rules and requirements engineering in a PLM system. IFAC Papers Online, 50(1), 7272-7277.

Främling, K., Ala-Risku, T., Kärkkäinen, M., \& Holmström, J. (2006). Agent-based model for managing composite product information. Computers in Industry, 57(1), 72-81.

Främling, K., Holmström, J., Loukkola, J., Nyman, J., \& Kaustell, A. (2013). Sustainable PLM through Intelligent Products. Engineering Applications of Artificial Intelligence, 26(2), 789-799.

Främling, K., Kubler, S., \& Buda, A. (2014). Universal messaging standards for the IoT from a lifecycle management perspective. Ieee Internet of Things Journal, 1(4), 319-327.

Garcia, P. B., \& Fan, I. S. (2008). Practitioner requirements for integrated knowledge-based engineering in Product Lifecycle Management. International Journal of Product Lifecycle Management, 3(1), 3-20.

Golovatchev, J. D., Budde, O., \& Hong, C. G. (2010). Integrated PLM-process-approach for the development and management of telecommunications products in a multi-lifecycle environment. International Journal of Manufacturing Technology and Management, 19(3-4), 224-237.

Gomes, S., Varret, A., Bluntzer, J. B., \& Sagot, J. C. (2009a). Functional design and optimization of parametric CAD models in a knowledge-based PLM environment. International Journal of Product Development, 9(1-3), 60-77.

Gomes, S., Monticolo, D., Hilaire, V., \& Eynard, B. (2009b). Content management based on multi-agent system for collaborative design. International Journal of Product Development, 8(2), 178-192.

Gort, A. (2015). Improving your product launch success. Industry Week, 254(4), 61-1.

Granros, R. (2009). Regulatory compliance for food safety. Control Engineering, 56(10)

Gulledge, T., \& Simon, G. (2009). Innovation and transformation using product lifecycle management enabled by NetWeaver. International Journal of Innovation and Learning, 6(1), 15-32.

Hachani, S., Gzara, L., \& Verjus, H. (2013). A service-oriented approach for flexible process support within enterprises: application on PLM systems. Enterprise Information Systems, 7(1), 79-99.

Hachani, S., Verjus, H., \& Gzara, L. (2012). Support of product design processes flexibility in PLM systems using 
a service-based approach. International Journal of Services Operations and Informatics, 7(4), 313-329.

Hazen, B. T., Overstreet, R. E., \& Boone, C. A. (2015). Suggested reporting guidelines for structural equation modeling in supply chain management research. International Journal of Logistics Management, 26(3), 627-641.

Hincapié, M., De Jesús Ramírez, M., Valenzuela, A., \& Valdez, J. A. (2014). Mixing real and virtual components in automated manufacturing systems using PLM tools. International Journal on Interactive Design and Manufacturing, 8(3)209230.

Holzer, D. (2014). Fostering the link from PLM to ERP via BIM the aec industry in transition. IFIP Advances in Information and Communication Technology, 442, 75-82.

Huang, G. Q., Wright, P. K., \& Newman, S. T. (2009). Wireless manufacturing: a literature review, recent developments, and case studies. International Journal of Computer Integrated Manufacturing, 22(7), 579-594.

Hughes, D., \& Taverna, M. A. (2004). Expanding the digital envelope. Aviation Week and Space Technology, 160(19), 50-52.

Ibrahim, R., \& Paulson, B. C. (2008). Discontinuity in organizations: identifying business environments affecting efficiency of knowledge flows in Product Lifecycle Management. International Journal of Product Lifecycle Management, 3(1), 21-36.

Ilieva, I., Meier, G., Schubert, P., \& Ovtcharova, J. (2009). Integration of Product Lifecycle Management (PLM) and Multi Project Management: toward increasing transparency in product development. Zwf Zeitschrift Fuer Wirtschaftichen Fabrikbetrieb, 104(11), 931-936.

Iosif, G., Iordache, I., Stoica, V., Luchian, A. M., Costea, E., Suciu, G., \& Suciu, V. (2018). Achieving a more electric aircraft: a comparative study between the concurrent and traditional engineering models. Incas Bulletin, 10(1), 221228.

Johnson, C., \& Gavilanes, J. (2003). Quick and below budget. Intech, Research Triangle, 50(5), 51-54.

Joshi, N., \& Dutta, D. (2008). Managing extended producer responsibility using PLM part 2: identification of joints for end-of-life treatment planning. Computer-Aided Design and Applications, 5(6), 764-773.

Jun, H., Kiritsis, D., \& Xirouchakis, P. (2007). Research issues on closed-loop PLM. Computers in Industry, 58(89), 855-868.

Jun, H.-B., Shin, J.-H., Kim, Y.-S., Kiritsis, D., \& Xirouchakis, P. (2009). A framework for RFID applications in product lifecycle management. International Journal of Computer Integrated Manufacturing, 22(7), 595-615.
Kahlert, T., \& Rezaie, A. (2005). Reporting-Strategien für PLM-Umgebungen. Zwf Zeitschrift Für Wirtschaftlichen Fabrikbetrieb, 100(9), 520-523.

Kang, L. (2008). Microfluidics for drug discovery and development: from target selection to product lifecycle management. Drug Discovery Today, 13(1-2), 1-13.

Kärkkäinen, H., \& Silventoinen, A. (2016). What is product lifecycle management (PLM) maturity? Analysis of current PLM maturity models. Journal of Modern Project Management, 3(3), 96-103.

Kiritsis, D. (2011). Closed-loop PLM for intelligent products in the era of the Internet of things. Computer Aided Design, 43(5), 479-501.

Kolle, S. R., Shankarappa, T. H., Arun, M., \& Reddy, T. B. M. (2017). Characteristics and trends in global lead removal research: a science citation index expanded-based analysis. Desalination and Water Treatment, 80, 164-173.

Kubler, S., Derigent, W., Voisin, A., Thomas, A., \& Rondeau, É. (2014). Method for embedding context-sensitive information on "communicating textiles" via fuzzy AHP. Journal of Intelligent \& Fuzzy Systems, 26(2), 597-610. http://dx.doi.org/10.3233/ifs-120753.

Kubler, S., Derigent, W., Främling, K., Thomas, A., \& Rondeau, É. (2015a). Enhanced Product Lifecycle Information Management using "communicating materials". Computer Aided Design, 59, 192-200.

Kubler, S., Främling, K., \& Derigent, W. (2015b). P2P Data synchronization for product lifecycle management. Computers in Industry, 66, 82-98.

Kultyshev, A. Y., Blagodarev, A. A., Gladkii, A. V., \& Shanturov, D. N. (2013). The experience of implementing and using the Windchill product lifecycle management system at the energy machine building enterprise. Thermal Engineering, 60(8), 559-566.

Lazarevic, M., Ostojic, G., Cosic, I., Stankovski, S. V., Vukelic, D., \& Zecevic, I. (2011). Product Lifecycle Management (PLM) methodology for product tracking based on RadioFrequency Identification (RFID) technology. Scientific Research and Essays, 6(22), 4776-4787.

Le Duigou, J. L., Bernard, A., \& Perry, N. (2011). Framework for Product Lifecycle Management integration in small and medium enterprises networks. Computer-Aided Design and Applications, 8(4), 531-544.

Lee, S. G., Ma, Y.-S., Thimm, G. L., \& Verstraeten, J. (2008a). Product Lifecycle Management in aviation maintenance, repair and overhaul. Computers in Industry, 59(2-3), 296303.

Lee, Y., Sheu, L., \& Tsou, Y. (2008b). Quality function deployment implementation based on Fuzzy Kano model: 
an application in PLM system. Computers \& Industrial Engineering, 55(1), 48-63.

Legardeur, J., Merlo, C., \& Fischer, X. (2006). An integrated information system for product design assistance based on artificial intelligence and collaborative tools. International Journal of Product Lifecycle Management, 1(3), 211-229.

Li, H.-F., \& Wu, H.-Z. (2005). Design and implementation of PLM based on meta-model driven. Jisuanji Jicheng Zhizao Xitong, 7, 963-968.

Li, J., Tao, F., Cheng, Y., \& Zhao, L. (2015). Big Data in product lifecycle management. International Journal of Advanced Manufacturing Technology, 81(1-4), 667-684.

Li, X.-S., \& Qi, G.-N. (2008). Integrated product model to support implementation of product lifecycle management. Journal of Zhejiang University, 42(3), 418-424.

Liao, X., \& Zhang, L. (2005). Access control model for workflow management system for PLM. Jisuanji Jicheng Zhizao Xitong, 11(10), 1367-1371.

Lin, W.-T., Wang, S.-T., Li, M.-H., Huang, J.-M., \& Chen, W.K. (2011). Modular fiber optic cable product architecture for application in Product Lifecycle Management. Information Technology Journal, 10(1), 16-28.

Löwer, M., \& Heller, J. E. (2014). PLM reference model for integrated idea and innovation management. IFIP Advances in Information and Communication Technology, 422(1), 257-266.

Lundin, M., Lejon, E., Dagman, A., Näsström, M., \& Jeppsson, P. (2017). Efficient design module capture and representation for product family reuse. Journal of Computing and Information Science in Engineering, 17(3)

Maier, F., Meyer, M., \& Steinbereithner, M. (2016). Nonprofit organizations becoming business-like: A systematic review. Nonprofit and Voluntary Sector Quarterly, 45(1), 64-86.

Marchetta, M. G., Mayer, F., \& Forradellas, R. Q. (2011). A reference framework following a proactive approach for Product Lifecycle Management. Computers in Industry, 62(7), 672-683.

Marconnet, B., Demoly, F., Monticolo, D., \& Gomes, S. (2017). An assembly oriented design and optimization approach for mechatronic system engineering. International Journal for Simulation and Multidisciplinary Design Optimization, 8(4), A7.

Marucheck, A., Greis, N., Mena, C., \& Cai, L. (2011). Product safety and security in the global supply chain: Issues, challenges and research opportunities. Journal of Operations Management, 29(7-8), 707-720.

Matsokis, A., \& Kiritsis, D. (2010). An ontology-based approach for Product Lifecycle Management. Computers in Industry, 61(8), 787-797.
Matsokis, A., \& Kiritsis, D. (2011). Ontology applications in PLM. International Journal of Product Lifecycle Management, 5(1), 84-97.

Mejía, R. G., Echeverri, C. M. C., Montoya, J. E. C., \& Álzate, A. F. G. (2016). Implementation of methodology of maintenance of molds of injection supported in tools of Product Lifecycle Management (PLM). Espacios, 37(25), 1-20.

Meloni, W. (2017). Growing by design. Computer Graphics World, 32-34.

Meng, X., Zhang, X., Ning, R., \& Song, Y. (2008). Enterprise integration platform based on service-oriented architecture. Chinese Journal of Mechanical Engineering, 21(3), 36-40.

Ming, X. G., Yan, J. Q., Wang, X. H., Li, S. N., Lu, W. F., Peng, Q. J., \& Ma, Y. S. (2008). Collaborative process planning and manufacturing in product lifecycle management. Computers in Industry, 59(2-3), 154-166.

Mo, R., Qiao, Y.-W., Chang, Z.-Y., Shi, Y., \& Chen, Z.-F. (2010). Validation informatization based on product lifecycle management-teamcenter. Jisuanji Jicheng Zhizao Xitong, 16(7), 1458-1464.

Nathan, S. (2009). Fast lane to production vehicle manufacturers are implementing PLM systems to better integrate development and manufacturing. Engineer, 294(7781), 38-40.

Navarro, R., Tiwari, A., \& Turner, C. (2013). Improving product lifecycle management implementations by applying 'lean' principles. International Journal of Product Lifecycle Management, 6(4), 357-380.

Neely, A. (2005). The evolution of performance measurement research: developments in the last decade and a research agenda for the next. International Journal of Operations \& Production Management, 25(12), 1264-1277.

Neil, S. (2009). A work in progress. Managing Automation, 24(4), 14-21.

Paavel, M., Karjust, K., \& Majak, J. (2017). Development of a product lifecycle management model based on the fuzzy analytic hierarchy process. Proceedings of the Estonian Academy of Sciences, 66(3), 279-286.

Palmarini, R., Erkoyuncu, J. A., Roy, R., \& Torabmostaedi, H. (2018). Systematic review of augmented reality applications in maintenance. Robotics and Computer-integrated Manufacturing, 49, 215-228.

Palmer, D. (2004). No-one pretends this is easy. Manufacturing Computer Solutions, 10(3), 35-36.

Piancastelli, L., Frizziero, L., Donnici, G., Di Giacomo, G., \& Gattii, A. (2015). Optimized FSI flow simulation using modern up-to-date software systems: A direct comparison between simulated and tunnel results. Journal 
of Engineering and Applied Sciences (Asian Research Publishing Network), 10(20), 9174-9182.

Pinna, C., Plo, L., Robin, V., Girard, P., \& Terzi, S. (2017). An approach to improve implementation of PLM solution in food industry - case study of Poult Group. International Journal of Product Lifecycle Management, 10(2), 151-170.

Pitcher, G. (2005). From cradle to grave. New Electronics, $38(7), 42-43$.

Polcar, J., \& Horejsi, P. (2015). Knowledge acquisition and cybersickness: a comparison of VR devices in virtual tours. Mm Science Journal, 2015(2), 613-616.

Portillo-Barco, C., \& Charnley, F. (2015). Data requirements and assessment of technologies enabling a product passport within products exposed to harsh environments: a case study of a high pressure nozzle guide vane. International Journal of Product Lifecycle Management, 8(3), 253-282.

Pullin, J. (2013). Making connections. Environmental Engineering, 26(2), 39-41.

Qiu, M., Chen, G., \& Dong, J.-X. (2015). Ontology based adaptive product lifecycle management system. Computer Integrated Manufacturing Systems - CIMS, 11(6), 825-830.

Rachuri, S., Subrahmanian, E., Bouras, A., Fenves, S. J., Foufou, S., \& Sriram, R. D. (2008). Information sharing and exchange in the context of product lifecycle management: role of standards. Computer Aided Design, 40(7), 789-800.

Ramos-Rodríguez, A., \& Ruíz-Navarro, J. (2004). Changes in the intellectual structure of strategic management research: a bibliometric study of the strategic management journal, 1980-2000. Strategic Management Journal, 25, 981-1004.

Ryan, T. J. (2003). Coming on strong. Apparel, 44(8), 27-32.

Sassanelli, C., Pezzotta, G., Pirola, F., Sala, R., Margarito, A., Lazoi, M., Corallo, A., Rossi, M., \& Terzi, S. (2018). Using design rules to guide the PSS design in an engineering platform based on the product service lifecycle management paradigm. International Journal of Product Lifecycle Management, 11(2), 91-115.

Savino, M. M., Mazza, A., \& Ouzrout, Y. (2012). PLM Maturity model: a multi-criteria assessment in southern Italy companies. International Journal of Operations and Quantitative Management, 18(3), 159-180.

Schmitt, P. (2007). PLM in aerospace. Manufacturing Engineering, 138(3).

Schuh, G., Rozenfeld, H., Assmus, D., \& Zancul, E. (2008). Process oriented framework to support PLM implementation. Computers in Industry, 59(2-3), 210-218.

Seibert, B. (2005). Design agility achieved with PDM/PLM. Apparel, 46(9), 22-26.
Sharma, A. (2005). Collaborative product innovation: integrating elements of CPI via PLM framework. Computer Aided Design, 37(13), 1425-1434.

Shelley, T. (2007). Controlling change. Manufacturing Computer Solutions, 13(5), 28-29.

Shen, J.-X., \& Zhou, R.-R. (2003). Research on PLM system framework and key technologies. Journal of Nanjing University of Aeronautics and Astronautics, 35(5), 565-571.

Shi, J.-G., Si, H., Wu, G., Su, Y., \& Lan, J. (2018). Critical factors to achieve dockless bike-sharing sustainability in China: A stakeholder-oriented network perspective. Sustainability, 10(6)

Simonova, L. A., \& Khisamutdinov, M. R. (2013). Scientific - industrial aspects of integration product lifecycle management and enterprise resource planning systems. World Applied Sciences Journal, 25(4), 690-693.

Skarka, W. (2005). Contemporary problems connected with including Standard for the Exchange of Product Model Data (ISO 10303 - STEP) in designing ontology using UML and XML. Computer Assisted Mechanics and Engineering Sciences, 12(2-3), 231-246.

Sodhro, A. H., Pirbhulal, S., \& Sangaiah, A. K. (2018). Convergence of IoT and product lifecycle management in medical health care. Future Generation Computer Systems, $86,380-391$.

Soto-Acosta, P., Placer-Maruri, E., \& Perez-Gonzalez, D. (2016). A case analysis of a product lifecycle information management framework for SMEs. International Journal of Information Management, 36(2), 240-244.

Spera, J. (2008). Manufacturing steps onto the enterprise IT stage. Circuits Assembly, 19(6), 28-29.

Srinivasan, V. (2011). An integration framework for product lifecycle management. Computer Aided Design, 43(5), 464-478.

Sriti, M.-F., Assouroko, I., Ducellier, G., Boutinaud, P., \& Eynard, B. (2015). Ontology-based approach for product information exchange. International Journal of Product Lifecycle Management, 8(1), 1-23.

Stark, J. (2011). Product Lifecycle Management. Decision Engineering, 1-562.

Stelzer, R., Petermann, D., Saske, B., \& Steger, W. (2009). Collaboration environment for computer aided design virtual reality (CAD-VR). Zwf Zeitschrift Fuer Wirtschaftlichen Fabrikbetrieb, 104(1-2), 89-93.

Stephens, S. (2006). PLM and steam generator replacement at SONGS. Nuclear News, 49(11), 47-50.

Sudarsan, R., Fenves, S. J., Sriram, R. D., \& Wang, F. (2005). A product information modeling framework for product 
lifecycle management. Computer Aided Design, 37(13), 1399-1411.

Tait, N. (2006). From point of conception to the point of sale: PLM - Yet another three letter acronym? Textile Network, 9, 40-43.

Takey, S. M., \& Carvalho, M. M. (2016). Fuzzy front end of systemic innovations: a conceptual framework based on a systematic literature review. Technological Forecasting and Social Change, 111, 97-109.

Talhi, A., Huet, J.-C., Fortineau, V., \& Lamouri, S. (2015). Toward an ontology-based architecture for cloud manufacturing. In T. Borangiu, A. Thomas \& D. Trentesaux (Eds.), Service Orientation in Holonic and Multi-agent Manufacturing. Studies in Computational Intelligence (pp. 187-195, Vol. 594). Cham: Springer.

Tang, D., \& Qian, X. (2008). Product lifecycle management for automotive development focusing on supplier integration. Computers in Industry, 59(2-3), 288-295.

Tang, G., \& Hu, L. (2015). A medical devices management information system supporting full life-cycle process management. Chinese Journal of Medical Instrumentation, 34(4), 304-308.

Taverna, M. A. (2004). New-fangled Falcon. Aviation Week and Space Technology, 161(14), 62-64.

Taverna, M. A. (2017). Time saver. Aviation Week and Space Technology (New York), 166(19), 60-61.

Teresko, J. (2004). Making a pitch for PLM. Industry Week, 253(8), 57-62.

Thilmany, J. (2011). Project and lifecycle together. Mechanical Engineering (New York, N.Y.), 133(2)

Tinham, B. (2003). Collaboration to slash $20 \%$ costs at Kvaerner. Manufacturing Computer Solutions, 9(1), 28-29.

Tinham, B. (2004). PLM: evolving tools for an evolving market? Manufacturing Computer Solutions, 10(4), 24-26.

Tran, A. (2006). Wanfeng auto holding group selects UGS' teamcenter express for cPDM. Automotive Industries Ai, 186(11), 1-1.

Trappey, A. J. C., \& Hsiao, D. W. (2008). Applying collaborative design and modularized assembly for automotive ODM supply chain integration. Computers in Industry, 59(2-3), 277-287.

Trotta, M. G. (2010). Product lifecycle management: sustainability and knowledge management as keys in a complex system of product development. Journal of Industrial Engineering and Management, 3(2), 309-322.

Vadoudi, K., Bratec, F., \& Troussier, N. (2017). A GIS-oriented semantic data model to support PLM for DfS. International Journal of Product Lifecycle Management, 10(3), 210-230.
Venkatasubramanian, V. (2005). Prognostic and diagnostic monitoring of complex systems for product lifecycle management: challenges and opportunities. Computers \& Chemical Engineering, 29(6), 1253-1263.

Venugopalan, S. R., Ganesh, L. S., \& Sai, L. P. (2012). Deployment maturity assessment of product lifecycle management systems: A study in Indian industries. International Journal Of Product Lifecycle Management, 6(2), 178-210.

Vezzetti, E., Moos, S., \& Kretli, S. (2011). A product lifecycle management methodology for supporting knowledge reuse in the consumer packaged goods domain. Computer Aided Design, 43(12), 1902-1911.

Vieira, D. R., Vieira, R. K., \& Chain, M. C. (2016). Elements of managerial integration for sustainable product lifecycle management. International Journal of Product Lifecycle Management, 9(2), 87-107.

Vila, C., Ugarte, D., Ríos, J., \& Abellán, J. V. (2017). Projectbased collaborative engineering learning to develop Industry 4.0 skills within a PLM framework. Procedia Manufacturing, 13, 1269-1276.

Von Buchstab, V. (2003). ABCs of CAD oversell. Design Engineering (London), 49(4)

Walker, A. J., \& Cox, J. J. (2008). Incorporating global characteristic data into virtual product development models. Computer-Aided Design and Applications, 5(6), 900-920.

Wan, J., Tang, S., Li, D., Wang, S., Liu, C., Abbas, H., \& Vasilakos, A. V. (2017). A manufacturing big data solution for active preventive maintenance. IEEE Transactions on Industrial Informatics, 13(4), 2039-2047.

Wang, C.-F., \& Xu, Y.-Q. (2005). Research on PLM for green manufacturing and its key technology. Zhuzao/foundry, 54(2), 108-111.

Wasike, B. (2017). Africa rising: an analysis of emergent Africa-focused mass communication scholarship from 2004 to 2014. International Journal of Communication, $11,198-219$.

Waurzyniak, P. (2014). Connecting the digital world with the factory floor: new collaborative $3 \mathrm{D}$ plant process planning and visualization tools are helping manufacturers prove out PLM's promise. Manufacturing Engineering, 154(4), 53-64.

Waurzyniak, P. (2015a). Programming ingenuity into manufacturing system: new software advances help manufacturers inject creativity and vision into their factoryfloor processes. Manufacturing Engineering, 154(10), 3-9.

Waurzyniak, P. (2015b). Redefining PLM. Manufacturing Engineering, 154(9), 117-126.

Waurzyniak, P. (2017). PLM's digital twins offer virtual view of manufacturing. Manufacturing Engineering, 158(4), 67-73. 
Wiens, D. (2006). Juggling WIP. New Electronics, 39(15), 38-39.

Wong, K. (2006). We gather today to join ERP and PLM: marrying enterprise data to product data. Cadalyst, 23(9), $42-44$.

Woods, T. (2005). Life aid. Engineering (London), 246(5), 38-39.

Yataganbaba, A., Ozkahraman, B., \& Kutbas, I. (2017). Worldwide trends on encapsulation of phase change materials: a bibliometric analysis (1990-2015). Applied Energy, 185, 720-731.

Yoo, M.-J., Um, J., Stroud, I., El Kadiri, S., \& Kiritsis, D. (2014). Integration of design intent during the product lifecycle management. IFIP Advances in Information and Communication Technology, 442, 101-110.

Young, C. (2012). Bridging the data divide. IBM Data Management Magazine, 6, 14.

Young, R. I. M., Gunendran, A. G., Cutting-Decelle, A. F., \& Gruninger, M. (2007). Manufacturing knowledge sharing in PLM: a progression towards the use of heavyweight ontologies. International Journal of Production Research, 45(7), 1505-1519.

Yu, H., Wei, Y., Tang, B., Mi, Z., \& Pan, S. (2016). Assessment on the research trend of low-carbon energy technology investment: a bibliometric analysis. Applied Energy, 184, 960-970.

Yu, Y., Yan, J.-W., \& Liu, M. (2010). Ontology mapping approach oriented to product information collaboration. Jisuanji Jicheng Zhizao Xitong, 16(5), 1111-1119.
Zhang, H., Ouzrout, Y., Bouras, A., \& Savino, M. M. (2014). Sustainability consideration within product lifecycle management through maturity models analysis. International Journal of Services and Operations Management, 19(2), 151-171.

Zhang, M.-J. Wang, Q.-H., Mo, X.-N., \& Zhang, L. (2011). Performance evaluation method for product lifecycle management. Jisuanji Jicheng Zhizao Xitong, 17(2), 362-368.

Zhang, Y., Ren, S., Liu, Y., \& Si, S. (2017a). A big data analytics architecture for cleaner manufacturing and maintenance processes of complex products. Journal of Cleaner Production, 142(2), 626-641.

Zhang, Y., Ren, S., Liu, Y., Sakao, T., \& Huisingh, D. (2017b). A framework for Big Data driven product lifecycle management. Journal of Cleaner Production, 159, 229-240.

Zhao, W.-B., Jeong, J.-W., Noh, S. D., \& Yee, J. T. (2015). Energy simulation framework integrated with green manufacturing-enabled PLM information model. International Journal of Precision Engineering and Manufacturing-Green Technology, 2(3), 217-224.

Zhu, H., Gao, J., Li, D., \& Tang, D. (2012). A web-based product service system for aerospace maintenance, repair and overhaul services. Computers in Industry, 63(4), 338-348.

Zhu, W., Bricogne, M., Durupt, A., Remy, S., Li, B., \& Eynard, B. (2016). implementations of model based definition and Product Lifecycle Management technologies: a case study in Chinese aeronautical industry. IFAC - Papers Online, 49(12), 485-490.

Zscheile, F. (2017). From machine files to maintenance history files. Productivity Management, 22(1), 62-65. 
Appendix 1. Author x Application Area.

\begin{tabular}{|c|c|}
\hline Author & Application area \\
\hline $\begin{array}{l}\text { Alemanni et al. (2008, 2010), Brière-Côté et al. (2010), Cantamessa et al. (2012), } \\
\text { Zhu et al. (2012, 2016), El Souri et al. (2017), Vieira et al. (2016), Navarro et al. (2013), } \\
\text { Venugopalan et al. (2012), Eynard et al. (2010), Taverna (2004, 2017), Schmitt (2007), } \\
\text { Hughes \& Taverna (2004), Teresko (2004), Anderson (2002) }\end{array}$ & Aerospace \\
\hline $\begin{array}{l}\text { Alemanni et al. (2010), Cao et al. (2009), Matsokis \& Kiritsis (2010), Srinivasan (2011), } \\
\text { Tang \& Qian (2008), Venugopalan et al. (2012), Baughey (2009), Shelley (2007), Tran } \\
\text { (2006), Case (2006), Brincheck (2005), Teresko (2004), Trappey \& Hsiao (2008) }\end{array}$ & Automotive \\
\hline Lee et al. (2008a) & Aviation maintenance, repair, and overhaul (MRO) \\
\hline Young (2012) & $\begin{array}{l}\text { Back-end systems, front-end commerce } \\
\text { applications, and the data warehouse }\end{array}$ \\
\hline Hachani et al. (2013) & Business Processes (BPs) \\
\hline Brezgin et al. (2013) & Cogeneration turbines \\
\hline Demoly et al. (2013) & Concurrent engineering \\
\hline Barthorpe et al. (2004), Holzer (2014) & Construction industry \\
\hline Vezzetti et al. (2011) & Consumer Packaged Goods (CPG) industry \\
\hline Sharma (2005) & CPI - Collaborative Product Innovation \\
\hline Cáceres et al. (2010) & Digital Manufacturing \\
\hline Iosif et al. (2018) & Electric aircraft \\
\hline Courtney (2014), Savino et al. (2012) & Electromechanical sectors \\
\hline Kultyshev et al. (2013) & Energy machine building enterprise \\
\hline Brunsmann et al. (2012) & Engineering industry \\
\hline D'Avolio et al. (2017) & Fashion companies \\
\hline Pinna et al. (2017) & Food industry \\
\hline Anderson (2002), Forcinio (2007) & Goods industries \\
\hline Kubler et al. (2015b) & Healthcare \\
\hline Venugopalan et al. (2012) & Hi-tech area \\
\hline Avventuroso et al. (2017), Vila et al. (2017) & Industry 4.0 \\
\hline Cai et al. (2014), Fortineau et al. (2013), Främling et al. (2014) & IoT \\
\hline Portillo-Barco \& Charnley (2015) & Jet engine \\
\hline $\begin{array}{l}\text { Shi et al. (2018), Camarillo et al. (2017), Marconnet et al. (2017), Essop et al. (2016), } \\
\text { Waurzyniak (2014), Bartholomew (2005), Wang \& Xu (2005), Trappey \& Hsiao (2008) }\end{array}$ & Manufacturing \\
\hline $\begin{array}{l}\text { Sodhro et al. (2018), Tang \& Hu (2015), Allanic et al. (2014), Kang (2008), Kubler et al. } \\
\text { (2015a) }\end{array}$ & Medical area \\
\hline Caro et al. (2011) & Naval shipbuilding \\
\hline Stephens (2006) & Nuclear energy \\
\hline Tinham (2003) & Oil and gas \\
\hline $\begin{array}{l}\text { Aziz et al. (2005), Borsato (2014), Cai et al. (2014), Chungoora et al. (2013), Demoly et al. } \\
\text { (2012), Fortineau et al. (2013), Kiritsis (2011), Matsokis \& Kiritsis (2010), Young et al. } \\
\text { (2007), Sriti et al. (2015), Talhi et al. (2015), Yoo et al. (2014), Matsokis \& Kiritsis (2011), } \\
\text { Yu et al. (2010), Borsato et al. (2010), Feng et al. (2009), Skarka (2005), Qiu et al. (2015) }\end{array}$ & Ontology \\
\hline Venkatasubramanian (2005) & Pharmaceutical \\
\hline Mejía et al. (2016) & Plastic injection \\
\hline Lazarevic et al. (2011) & Radio-frequency identification (RFID \\
\hline Falkiewicz (2011) & $\begin{array}{l}\text { Sales, purchasing, accounting, manufacturing, and } \\
\text { service. }\end{array}$ \\
\hline Gulledge \& Simon (2009) & Single Army Logistics Enterprise (SALE) \\
\hline Marucheck et al. (2011) & Safety and security \\
\hline $\begin{array}{l}\text { Le Duigou et al. (2011), Zhang et al. (2011), Alison (2010), Pitcher (2005), Tinham (2004), } \\
\text { Bruno et al. (2016) }\end{array}$ & Small and medium enterprises (SME's) \\
\hline Främling et al. (2013), Zhao et al. (2015), Trotta (2010) & Sustainable area \\
\hline Mo et al. (2010) & Teamcenter (TC) architecture \\
\hline Golovatchev et al. (2010) & Telecommunications industry \\
\hline Zhang et al. (2017b) & Turbomachinery \\
\hline Bonou et al. (2016) & Wind turbines \\
\hline
\end{tabular}


Appendix 2. Author x Keywords.

\begin{tabular}{|c|c|}
\hline Authors & Keywords \\
\hline Iosif et al. (2018) & 2D/3D design software \\
\hline Brière-Côté et al. (2010) & Adaptive Generic Product Structure (AGPS) \\
\hline Chen et al. (2008) & Analytic network process (ANP) \\
\hline Trappey \& Hsiao (2008) & Advanced product quality planning (APQP) \& \\
\hline Gomes et al. (2009b) & Atelier Cooperatif de Suivi de Projet in French (ACSP) \\
\hline El Souri et al. (2017) & BAE Systems \\
\hline Liao \& Zhang (2005) & Based Access Control Model (RBAC) \\
\hline Zhang et al. (2017a), Li et al. (2015), Wan et al. (2017), & Big Data \\
\hline Marchetta et al. (2011) & Business Process Model (BPM) \\
\hline $\begin{array}{l}\text { Lundin et al. (2017), Waurzyniak (2015a, 2015b, 2017), Zscheile (2017), } \\
\text { Farish (2008, 2012), Ding et al. (2011), Gomes et al. (2009a), Neil } \\
\text { (2009), Walker \& Cox (2008), Shelley (2007), Sudarsan et al. (2005), } \\
\text { Lundin et al. (2017), Zscheile (2017), Lee et al. (2008a), Denkena et al. } \\
\text { (2007), Alemanni et al. (2010), Ming et al. (2008) }\end{array}$ & Computer-aided design (CAD) \\
\hline Piancastelli et al.(2015). & CADembedded FSI (Fluid System Interaction) \\
\hline $\begin{array}{l}\text { Waurzyniak (2015a, 2015b, 2017), Pullin (2013), Falkiewicz (2011), } \\
\text { Walker \& Cox (2008), Teresko (2004), Sudarsan et al. (2005), Lee et al. } \\
\text { (2008a), Ming et al. (2008) }\end{array}$ & Computer-aided engineering (CAE) \\
\hline $\begin{array}{l}\text { Waurzyniak (2015a, 2015b, 2017), Walker \& Cox (2008), Shelley (2007), } \\
\text { Meloni (2007), Woods (2005), Teresko (2004), Sudarsan et al. (2005), } \\
\text { Lee et al. (2008a), Denkena et al. (2007), Ming et al. (2008) }\end{array}$ & Computer-aided manufacturing (CAM) \\
\hline Denkena et al. (2007), Ming et al. (2008) & Computer Aided Process Planning (CAPP) \\
\hline Nathan (2009), Palmer (2004) & CATIA PLM \\
\hline Chungoora et al. (2013) & Computation Independent Model (CIM) \\
\hline Kärkkäinen \& Silventoinen (2016) & Capability maturity modeling (CMM) \\
\hline Sharma (2005) & Collaborative Product Innovation (CPI) \\
\hline Lundin et al. (2017), Vila et al. (2017), Shen \& Zhou (2003). & Computer-aided technologies (CAx) \\
\hline Cole (2009) & Concept2Market (C2M) \\
\hline Borsato (2014) & Core Product Model / Open Assembly Model (CPM/OAM) \\
\hline Cui et al. (2008) & Customer architecture hierarchy $(\mathrm{CAH})$ method \\
\hline Young (2012), Bartholomew (2004), Shen \& Zhou (2003), & Customer relationship management (CRM) \\
\hline Fortineau et al. (2017) & Data Linked Through Occurrences Network (DALTON) \\
\hline Hincapié et al. (2014) & Dassault Systemes (DELMIA) \\
\hline Lee et al. (2008b) & Delphi methods \\
\hline Ducellier et al. (2014) & Design Change Orders (DCO) \\
\hline Wiens (2006) & Design data management (DDM) system. \\
\hline Anišić et al. (2013) & Design for Excellence (DFX) \\
\hline Marconnet et al. (2017) & Design For Manufacturing and Assembly (DFMA) \\
\hline Vadoudi et al. (2017) & Design for sustainability (DfS) \\
\hline Dhuieb (2014) & Digital Factory Assistant (DFA) \\
\hline Sodhro et al. (2018) & Duty-cycle optimization-based (JEHDO) algorithm \\
\hline Case (2006) & Electrical control unit (ECU) \\
\hline Zhao et al. (2015) & EnergyPlus' program \\
\hline $\begin{array}{l}\text { Tang \& Hu (2015), Holzer (2014), Simonova \& Khisamutdinov } \\
\text { (2013), Young (2012), Falkiewicz (2011), Wong (2006), Gort (2015), } \\
\text { Barthorpe et al. (2004), Shen \& Zhou (2003) }\end{array}$ & Enterprise Resource planning (ERP) \\
\hline Li \& Wu (2005) & Extensible Markup Language (XML) \\
\hline Tait (2006) & Fashion Lifecycle Management (FLM) \\
\hline Shelley (2007) & Finite element analysis (FEA) computation \\
\hline Paavel et al. (2017), Kubler et al. (2014), Lee et al. (2008b) & Fuzzy analytic hierarchy process [FAHP] \\
\hline Granros (2009) & Hazard Analysis and Critical Control Points (HACCP) \\
\hline Portillo-Barco \& Charnley (2015) & High pressure nozzle guide vane (HPNGV) \\
\hline Främling et al. (2014) & Hypertext transfer protocol (HTTP) \\
\hline Chungoora et al. (2013) & Knowledge Systems (IMKS) \\
\hline Holzer (2014) & Information Modeling (BIM) \\
\hline
\end{tabular}


Appendix 2. Continued...

\begin{tabular}{|c|c|}
\hline Authors & Keywords \\
\hline Legardeur et al. (2006) & Innovation Development and Diffusion (ID2) system \\
\hline Li \& Qi (2008) & Integrated product model (IPM) \\
\hline Camarillo et al. $(2017,2018)$, Shi et al. (2018) & Integrates Case-Based Reasoning (CBR) \\
\hline Lee et al. (2008b) & Kano model \\
\hline Al-Ashaab et al. (2012) & Knowledge-based environment (KBEnv) \\
\hline Al-Ashaab et al. (2012) & $\begin{array}{l}\text { Knowledge-Based Environment to Support Product Design } \\
\text { Validation (KBE) }\end{array}$ \\
\hline Garcia \& Fan (2008) & Knowledge Management (KM) \\
\hline \multicolumn{2}{|l|}{ Ibrahim \& Paulson (2008). } \\
\hline Bonou et al. (2016). & Life cycle management (LCM) \\
\hline Chiappinelli (2008). & Manufacturing execution software (MES) \\
\hline \multicolumn{2}{|l|}{ Johnson \& Gavilanes (2003) } \\
\hline Spera $(2008)$ & Manufacturing operations system (MOS) software \\
\hline Camarillo et al. (2018) & Manufacturing Problem Solving (MPS) \\
\hline Tinham (2004) & MatrixOne and Smartteam \\
\hline Abid et al. (2014) & Mechatronic system e System Modelling Language (SysML). \\
\hline Sodhro et al. (2018) & Medical Things (IoMT) \\
\hline Zhu et al. (2016) & Model-Based Definition (MBD) \\
\hline Li \& Wu (2005), Chungoora et al. (2013) & Model-Driven Architecture (MDA) \\
\hline Aziz et al. (2005) & MySQL \\
\hline Ilieva et al. (2009) & Multi-Project Management (MPM) \\
\hline Venugopalan et al. (2012) & New product development (NPD) \\
\hline Srinivasan (2011) & OMG PLM Services \\
\hline Fortineau et al. (2013) & OntoStep \\
\hline Srinivasan (2011) & $\begin{array}{l}\text { Open Applications Group Integration Specifications OAGIS } \\
\text { BODs }\end{array}$ \\
\hline Joshi \& Dutta (2008) & Original Equipment Manufacturers (OEMs) \\
\hline Demoly et al. $(2010,2011 a, 2013)$ & $\begin{array}{c}\text { Product design Engineering based on Generative Assembly } \\
\text { Sequences planning (PEGASUS) }\end{array}$ \\
\hline Huang et al. (2009), Jun et al. (2009), Cao et al. (2009) & Product embedded information devices (PEIDs) \\
\hline Marchetta et al. (2011), Chungoora et al. (2013). & Product Information Model (PIM) \\
\hline Soto-Acosta et al. (2016) & Pladomin \\
\hline Chungoora et al. (2013) & Platform Specific Model (PSM) \\
\hline Camarillo et al. (2018) & Process Failure Mode and Effect Analysis (PFMEA) \\
\hline Young et al. (2007) & Process Specification Language (PSL) \\
\hline $\begin{array}{l}\text { Paavel et al. (2017), Löwer \& Heller (2014), Falkiewicz (2011), } \\
\text { Cummings (2006), Crawford (2006), Seibert (2005), Kahlert \& Rezaie } \\
\text { (2005), Ryan (2003), Von Buchstab (2003) }\end{array}$ & Product Data Management (PDM) \\
\hline Löwer \& Heller (2014) & Product Data Management Systems (PDMS) \\
\hline $\begin{array}{l}\text { Kiritsis (2011), Främling et al. (2014), Huang et al. (2009), Jun et al. } \\
\text { (2009), Cao et al. (2009), Kubler et al. (2015a) }\end{array}$ & $\begin{array}{c}\text { Product Lifecycle Management and Information Tracking using } \\
\text { Smart Embedded Systems (PROMISE) }\end{array}$ \\
\hline Sassanelli et al.(2018) & Product service systems (PSSs) \\
\hline Thilmany (2011). & Project portfolio management (PPM) \\
\hline Bruun et al. (2015) & PTC Windchill PDMLink 9.1. \\
\hline Lee et al. (2008b), Vezzetti et al. (2011) & Quality Function Deployment (QFD) \\
\hline $\begin{array}{l}\text { Främling et al. (2014), Främling et al. (2013), Tang \& Qian (2008), } \\
\text { Kubler et al. (2015a) }\end{array}$ & Quantum lifecycle management (QLM) \\
\hline $\begin{array}{l}\text { Kiritsis (2011), Huang et al. (2009), Jun et al. (2009), Cao et al. (2009), } \\
\text { Kubler et al. (2015a) }\end{array}$ & Radio frequency identification (RFID) \\
\hline Feng et al. (2010) & Reliability, Maintainability and Supportability (RMS) \\
\hline Camarillo et al. (2018) & $\begin{array}{c}\text { Shared Experience using an Agent-based System Architecture } \\
\text { LayouT (SEASALT) }\end{array}$ \\
\hline Chen et al. (2008) & Sensitivity analysis \\
\hline Demoly et al. (2012) & Semantic WebRuleLanguage (SWRL) \\
\hline
\end{tabular}


Appendix 2. Continued...

\begin{tabular}{|c|c|}
\hline Authors & Keywords \\
\hline $\begin{array}{l}\text { Hachani et al. (2012), Baughey (2009), Meng et al. (2008), Srinivasan } \\
(2011)\end{array}$ & Server-Oriented Architecture (SOA) \\
\hline Al-Ashaab et al. (2012) & Siemens Teamcenter Software (TcSE) \\
\hline Demoly et al. (2011b) & $\begin{array}{l}\text { SKeLeton geometry-based Assembly Context Definition } \\
\text { (SKLACD) }\end{array}$ \\
\hline Kiritsis (2011), Srinivasan (2011) & Standard for the Exchange of Product data model (STEP) \\
\hline Zhang et al. (2014) & TechnoWare, InforWare, FunctionWare, and OrgaWare (TIFO) \\
\hline Vezzetti et al. (2011) & Teoriya Resheniya Izobreatatelskikh Zadatch (TRIZ) \\
\hline $\operatorname{Tran}(2006)$ & UGS' Teamcenter Express \\
\hline $\begin{array}{l}\text { Vadoudi et al. (2017), Eynard et al. (2010), Li \& Wu (2005), } \\
\text { Sudarsan et al. (2005), Matsokis \& Kiritsis (2010), Srinivasan (2011), } \\
\text { Zhao et al. (2015), Demoly et al. (2013), Young et al. (2007), Cao et al. } \\
(2009)\end{array}$ & Unified Modeling Language (UML) \\
\hline Kultyshev et al. (2013) & Ural Turbine Works (UTW) \\
\hline Lin et al. (2011) & Value Stream Mapping (VSM) \\
\hline Polcar \& Horejsi (2015), Stelzer et al. (2009) & Virtual Reality (VR) \\
\hline Zhu et al. (2012) & World Wide Web Consortium (W3C) \\
\hline $\begin{array}{l}\text { Yoo et al. (2014), Matsokis \& Kiritsis (2010), Fortineau et al. (2013), } \\
\text { Zhu et al. (2012), Demoly et al. (2012) }\end{array}$ & Web Ontology Language (OWL) \\
\hline Adami-Sampson (2007) & $\begin{array}{l}\text { Waste electrical and electronic equipment, Restriction of } \\
\text { hazardous substances, and end of life Vehicle } \\
\text { (WEEE, RoHS, and ELV). }\end{array}$ \\
\hline Alemanni et al. (2008) & Wide Alenia space Network Data (WAND) \\
\hline Feng et al. (2009) & Windchill FIexPLM \\
\hline Liao \& Zhang (2005) & Workflow Management System (WfMS) \\
\hline
\end{tabular}

